\title{
Giantism in Oligocene planktonic foraminifera Paragloborotalia opima: Morphometric constraints from the equatorial Pacific Ocean
}

\author{
Bridget S. Wade ${ }^{1,2 *}$, Christopher R. Poole ${ }^{2}$, and Jamie L. Boyd ${ }^{1}$
}

With 7 figures, 7 plates and 1 table

\begin{abstract}
The extinction of Oligocene planktonic foraminifera Paragloborotalia opima is an important biostratigraphic marker for the upper Oligocene (base Zone O6 [P22]), however the taxonomy of the morphospecies is unclear and therefore its biostratigraphic use is compromised. We conducted morphometric and scanning electron microscope analyses on the Paragloborotalia opima-nana plexus and investigated whether the two morphospecies P.opima (Bolli) and P.nana (Bolli) could be quantitatively separated or formed a continuous morphocline. These two morphospecies have previously been classified by their diameter, with P.opi$m a$ defined as the larger morphospecies $(0.39-0.55 \mathrm{~mm})$ and P.nana confined to $<0.32 \mathrm{~mm}$. The problem with this classification is that many specimens fall between 0.32 and $0.39 \mathrm{~mm}$. We measured the maximum size of 1215 specimens of Paragloborotalia from equatorial Pacific Ocean Integrated Ocean Drilling Program Site U1334, corresponding to planktonic foraminiferal Biozones O6-O2 and Chrons C8r to C11r (26.3 to $30.8 \mathrm{Ma}$ ). We found that the number of chambers and shape outline could not be used to determine these two morphotypes of Paragloborotalia, but size is a suitable delimiting character. We therefore reassess the taxonomy of the opima-nana plexus. Our data confirm that the 'transition' forms are consistent with P.opima and that the $0.32 \mathrm{~mm}$ criterion is valid for the identification of P.nana. Through the studied interval the maximum size of P.opima increases from $0.44 \mathrm{~mm}$ to $0.68 \mathrm{~mm}$, with the largest specimens in the upper Oligocene in the lower part of Chron C9n. We propose that the progressive giantism of P.opima through the mid-late Oligocene in the equatorial Pacific Ocean is in response to high productivity.
\end{abstract}

Key words. Planktonic foraminifera, morphometrics, taxonomy, size, giantism, extinction

\section{Introduction}

\subsection{Paragloborotalia}

Paragloborotalia are an abundant group of planktonic foraminifera (calcareous marine zooplankton) ranging from the Eocene through to the late Miocene. They are globally distributed in low and mid latitudes. Cifelli
(1982) erected the genus Paragloborotalia which is characterized by a spinose, normal perforate, coarsely cancellate, sacculifer-type wall texture, with strongly embracing chambers arranged in a low trochospire, and an umbilical-extraumbilical aperture with a lip (Olsson et al. 2006). Stable isotope investigations indicate relatively positive $\delta^{18} \mathrm{O}$ values in paragloborotaliids in comparison to the rest of the assemblage,

\footnotetext{
Authors' addresses:

1 School of Earth and Environment, University of Leeds, Woodhouse Lane, Leeds, LS2 9JT, UK.

2 Department of Earth Sciences, University College London, Gower Street, London, WC1E 6BT, UK.

E-Mail addresses: b.wade@ucl.ac.uk; christopher.poole@ucl.ac.uk; ee08j1l@leeds.ac.uk

* Corresponding author: b.wade@ucl.ac.uk
} 
suggesting calcification in the thermocline (Poore and Matthews 1984, Wade et al. 2007, Pearson and Wade 2009, Moore et al. 2014).

\subsection{Paragloborotalia opima-nana plexus}

Bolli (1957) described two subspecies that are significant in the Oligocene: Globorotalia opima nana (Plate 1.1) and Globorotalia opima opima (Plate 1.2 and 1.3).Paragloborotalia opima is the type species of the genus and descended from Paragloborotalia nana in the early Oligocene (Bolli 1957, Olsson et al. 2006). These two forms were originally described as separate subspecies due to their test size disparity and different extinction levels. The stratigraphic range of P.opima is significantly restricted compared to that of P.nana and consequently is utilised as an expedient index fossil. The extinction of P.opima is an important biostratigraphic event and the limited stratigraphic range of P.opima has been widely utilised in all Oligocene

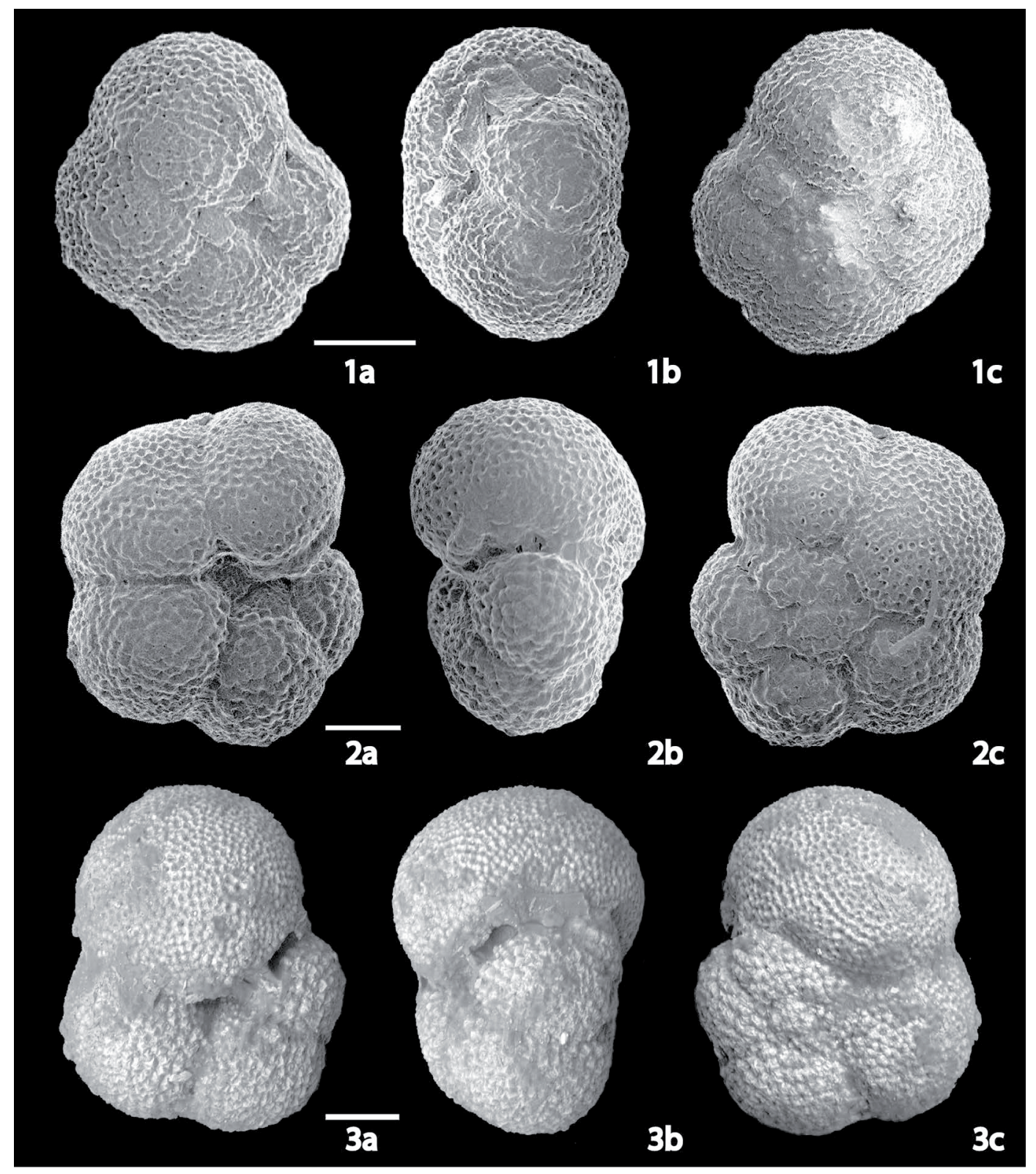

Plate 1. (1a-c) Holotype of Globorotalia opima nana Bolli, 1957; (2a-c) Holotype of Globorotalia opima opima Bolli, 1957; (3a-c) Paratype of Globorotalia opima opima (USNM 5660) Bolli, 1957, Globorotalia opima opima Zone (Zone O5) Cipero Fm, Trinidad. Scale bar $=100$ microns. 
Table 1 Size classes of Paragloborotalia opima-nana specimens (maximum test diameter) as per Bolli and Saunders (1985).

\begin{tabular}{lll}
\hline $\begin{array}{l}\text { Size Range } \\
\text { (maximum test diameter, } \mathrm{mm})\end{array}$ & Assigned Species & Taxonomic Notes \\
\hline $0.25-0.32$ & $\begin{array}{l}\text { P.nana } \\
\text { Intermediate } \\
\text { ('transitional') species } \\
\text { P.opima }\end{array}$ & $\begin{array}{l}\text { 'Typical' four-chamber arrangement in final whorl } \\
\text { Commonly five chambers in the final whorl. Perhaps ancestral } \\
\text { to P. mayeri rather than within the } \text { P.opima-nana } \text { plexus }\end{array}$ \\
$0.39-0.43$ & $\begin{array}{l}\text { Deficient of the last chamber; less developed forms seemingly } \\
\text { represent less mature specimens of those from the largest size } \\
\text { range (therefore assigned to } \text { P.opima) } \\
\text { 'Typical' four-chamber arrangement in final whorl }\end{array}$ \\
$0.45-0.50$ (or larger) & P.opima &
\end{tabular}

planktonic foraminiferal zonal schemes since the 1950s (Bolli 1957). The highest occurrence has been calibrated to mid Chron C9n at Site 1218 (Wade et al. 2007).

Bolli and Saunders (1985) stated that the number of chambers and chamber arrangement were common to both morphospecies. Paragloborotalia nana is considered as having a conservative morphology of four compact chambers (Olsson et al. 2006). The holotype of opima opima is actually a five chambered form (Plate 1), which are relatively infrequent in Oligocene assemblages (and indeed in our studied samples). Bolli recognised this and stated "only rarely does one find specimens with five chambers. Such an unusual specimen was unfortunately chosen as the holotype for G.opima opima" (Bolli and Saunders, 1985, p. 202).

Bolli and Saunders (1985) measured the maximum diameter of P.opima-nana plexus specimens from the type locality in Trinidad, to evaluate whether size restrictions could be used to separate the two 'subspecies'. They found that four size classes could be distinguished (see Table 1). The two extreme size classes, $<0.32 \mathrm{~mm}$ and $>0.45 \mathrm{~mm}$, clearly represent P.nana and P.opima respectively. Bolli and Saunders (1985) also recognised two intermediate size classes (0.32-0.38 and $0.39-0.43 \mathrm{~mm})$. According to the classification, the $0.39-0.43 \mathrm{~mm}$ grouping also corresponds to $P$.opima (i.e. all forms $>0.39 \mathrm{~mm}$ represent P.opima; see Table 1 for explanation). The other intermediate $0.32-0.38 \mathrm{~mm}$ grouping was atypical of P.opima-nana forms, as the final whorls commonly comprised five chambers (although apparently exhibited no other significant morphological differences; Bolli and Saunders 1985). They suggested these forms may actually represent ancestral forms of P.mayeri; unrelated to the P.opima-nana plexus. Unfortunately
Bolli and Saunders (1985) did not provide details of how many specimens were measured or the raw data. Furthermore, measurements from one locality (Trinidad) may not be applicable to populations elsewhere.

Disparate workers have treated the opima-nana plexus in different ways. Some studies adopt the size criterion approach established by Bolli and Saunders (1985), whereby $<0.32 \mathrm{~mm}$ forms and $>0.39 \mathrm{~mm}$ forms are considered P.nana and P.opima respectively (e.g., Miller et al. 1985, Leckie et al. 1993, Pearson and Chaisson 1997, Wade et al. 2007). Although Bolli's (1957) original descriptions highlight the only morphological difference to be test size, another taxonomic concept has been used to distinguish the two morphotypes, based on outline morphology, irrespective of size (e.g., Jenkins 1960, Spezzaferri 1994). Jenkins (1960) restricted his concept of P.nana to the four chambered forms, and P.opima to the 5 chambered forms, regardless of specimen size. Spezzaferri (1994) lists several criteria other than size (frequency of apertural rim, profile lobateness, chamber expansion rate, whorl number) to discern between the two morphospecies.

Further, problems in taxonomic definition arise as many specimens consistent with the taxonomic concept of the opima-nana plexus are in the transitional $0.32-0.38 \mathrm{~mm}$ size range of Bolli and Saunders (1985), resulting in many forms being referred to as 'opima-nana transitions' (Wade et al. 2007, plate I, figs. $\mathrm{h}-\mathrm{m})$. Whilst it is clear that larger forms do not occur in the latest Oligocene, P.opima and P.nana remain problematic to delimit, which makes the true extinction event of P.opima hard to define and accurately constrain its timing. Indeed, difficulties in identifying "typical" P.opima have led to uncertainties in biostratigraphic zonal boundaries (e.g., Poore et al. 1982, 
1983, Poore 1984). Both the size and 'quadrateness' morphospecies concepts have considerable ambiguity with regards to morphological delimitation because of transitional forms. While a more morphological approach is valid in a palaeontological sense, these determinations do not follow the taxonomic size-based concepts established by Bolli (1957) and subsequently Bolli and Saunders (1985) when describing each morphospecies. Furthermore several workers have not stated their taxonomic concepts for P.opima (e.g., Poore 1984, Flower and Chisholm 2006, Coccioni et al. 2013). Two fundamental problems encumber the ability to confidently assign specimens of the plexus to either P.opima or P.nana; 1) Ambiguity regarding intermediate-sized ('transitional') specimens remains prevalent despite the extensively utilised size-based classification of Bolli and Saunders (1985); 2) The taxonomic decision as to whether a specimen qualifies as 'quadrate' is inherently subjective (as it is qualitative rather than quantitative) and is inconsistent with sized-based concepts. We test the size classifications of Bolli and Saunders (1985) and the usefulness of the 'quadrateness' concept, through morphometric analysis of specimens from the equatorial Pacific Ocean.

\subsection{Oligocene biostratigraphy}

The P.opima and P.nana morphotypes have historically been described as separate species (or at least subspecies), but the intermediate-sized, 'transitional' specimens clearly highlight that P.opima and P.nana are end-member morphotypes of a morphological continuum (or plexus). We thus refer to P.opima and P. nana as morphospecies, although it remains equitable to

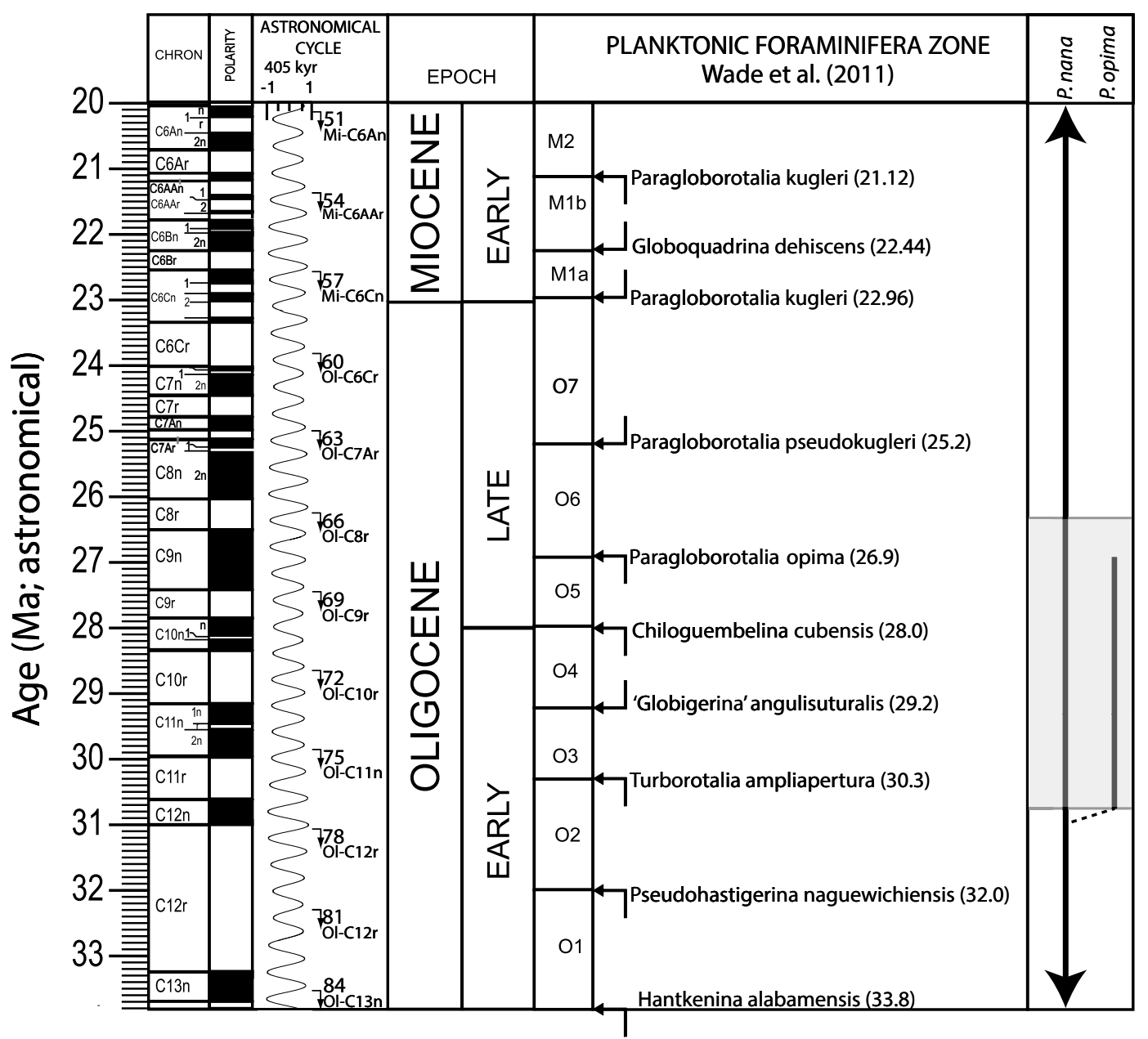

Fig. 1. Planktonic foraminifera zonation of the Oligocene (Wade et al. 2011) against the astronomical time scale of Pälike et al. (2006) with $405 \mathrm{kyr}$ cycles as per Wade and Pälike (2004). The grey shaded area indicates the study interval at Site U1334. 
consider P.opima and P.nana as separate species due to the incongruence of their extinction events (Fig. 1). To utilise the restricted biostratigraphic range of the larger P.opima, a resolution of the taxonomy and consistent separation of the opima-nana plexus is required. The lowest occurrence of P.opima has been used as a zonal boundary marker in the early Oligocene (Bolli 1957, 1966, Blow and Banner 1962, Bolli and Saunders 1985), though is now used as a secondary bioevent within Zone $\mathrm{O} 2$ (Wade et al. 2011). The larger (P.opi$m a$ ) forms suffer a global extinction event which demarcates the base of late Oligocene planktonic foraminiferal Zone O6 [P22] (e.g., Wade et al. 2007, 2011). Both forms are common in Zone O5, but only smaller (P.nana) forms continue into Zone O6.

The contrasting taxonomic concepts produce markedly inconsistent stratigraphic levels of extinction. Using a 'quadrate' taxonomic concept (e.g., Spezzaferri 1994) would mean that all sites (globally) would show a large size reduction, as opposed to an extinction of P.opima. Of the smaller forms that persist into Zone O6, not all specimens will qualify as 'quadrate', which therefore results in specimens that could be classified as P.opima (i.e. less quadrate forms) persisting past their currently accepted extinction level and contrasting (younger) stratigraphic levels for the P.opima extinction. These taxonomic concepts raise further questions as to what qualifies as a 'typical' P.opima or P.nana morphotype.

We aimed to differentiate the opima-nana plexus using a reproducible quantitative morphometric approach and thus facilitate the identification of this important biostratigraphic boundary. Morphological features are normally defined qualitatively, but size is a parameter that can be readily determined quantitatively with the light microscope. In addition to size we performed outline shape analyses on a subsection of our dataset. We utilised the abundant assemblages of Paragloborotalia from IODP Expedition 320/321 Site U1334, and conducted morphometric and scanning electron microscope analyses to assess the currently used morphospecies concepts and to determine the mode and tempo of morphological change. We addressed the following objectives:

1) Document the size range of Oligocene species of Paragloborotalia opima-nana plexus.

2) Determine if the opima-nana plexus had a bimodal or unimodal size distribution.

3) Establish the timing and rapidity of size changes and relationship (if any) to palaeoenvironmental change.

\section{Materials and methods}

\subsection{Location}

Integrated Ocean Drilling Program Expedition 320/ 321 "Pacific Equatorial Age Transect" (Sites U1331U1338) recovered Cenozoic sediments of the palaeoequatorial Pacific Ocean (Expedition 320/321 Scientists 2010). Site U1334 (Fig. 2, $7^{\circ} 59$ N, 131 ${ }^{\circ} 58 \mathrm{~W}$; 4799 meters below sea level) recovered a chalk and nannofossil ooze succession from the middle Miocene to the uppermost middle Eocene, with abundant calcareous microfossils and $\mathrm{CaCO}_{3}$ values near $90 \mathrm{wt} \%$ in the Oligocene. Sedimentation rates are $\sim 15 \mathrm{~m} / \mathrm{myr}$, but vary between 14 and $24 \mathrm{~m} / \mathrm{myr}$ (Expedition 320/ 321 Scientists 2010). Site U1334 is above the carbonate compensation depth for the entire study interval (Pälike et al. 2012).

Planktonic foraminiferal analysis was conducted from Hole U1334A from cores $15 \mathrm{H}-4$ to $22 \mathrm{H}-5$, equivalent to 136.64 to 204.64 meters below sea floor (mbsf) and 155.59 to 247.10 core composite depth below sea floor (CCSF-A) (m) (Expedition 320/321 Scientists 2010, Westerhold et al. 2012). This interval corresponds to planktonic foraminiferal Zones O6 to $\mathrm{O} 2$ (King and Wade, submitted), and Chron C8r through C11r, equivalent to 26.3 to $30.8 \mathrm{Ma}$. All data

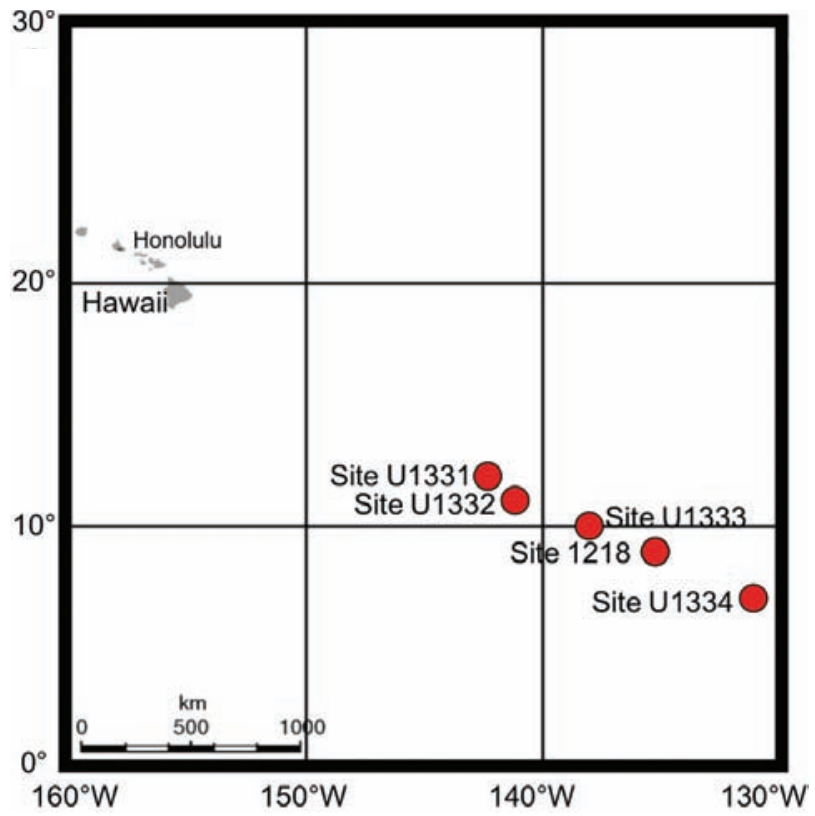

Fig. 2. Location of Site U1334 and the nearby sites from the IODP Expedition 320/321 and Site 1218 from ODP Leg 199, equatorial Pacific Ocean (modified after Wade et al. 2007). 
are calibrated to the Pälike et al. (2006) timescale using the magneto- and astro-chronology at Site U1334 (Westerhold et al. 2012). Samples were taken every section $(1.5 \mathrm{~m})$ providing a temporal resolution of $\sim 95$ kyr. Samples were washed over a $63 \mu \mathrm{m}$ sieve, and the $>125 \mu \mathrm{m}$ size fraction was examined and all P.opima-nana specimens were picked for morphometric analysis.

\subsection{Morphometrics}

We used morphometric analyses to quantitatively differentiate the opima-nana plexus. Morphometric analyses were conducted on 1215 specimens of Paragloborotalia from Site U1334 (Appendix 1). Specimens were orientated under the light microscope in umbilical view and the maximum diameter (marked $\alpha$ on Plate 2) was measured using an eyepiece graticule. Selected specimens were re-measured using the scanning electron microscope (SEM) to confirm light microscope results. As we were primarily interested in maximum size, we did not measure the $<355 \mu \mathrm{m}$ size fraction for all samples, but rather concentrated on the largest forms.

We tracked the distribution and size of Paragloborotalia in six discrete samples from Site U1334 to study if they have a unimodal or bimodal distribution in sample size. The sample was dry sieved into four size fractions: $63-125 \mu \mathrm{m}, 125-250 \mu \mathrm{m}, 250-$ $355 \mu \mathrm{m}$, and $>355 \mu \mathrm{m}$. All Paragloborotalia opimanana specimens were counted and measured (Appen$\operatorname{dix} 1)$.

Morphometric studies, beyond maximum size, are required to resolve the morphological definitions of the P.opima and P.nana morphotypes. Morphological parameters of more than 300 specimens from Site U1334 were obtained using image analysis software (Image-Pro Premier; Appendix 2). Parameters measured included:

1. Maximum and minimum diameter $(\mu \mathrm{m})$

2. Area $\left(\mu \mathrm{m}^{2}\right)$

3. Aspect ratio (maximum diameter/minimum diameter)

4. Circularity (value between 0 and 1 , where 0 shows least circularity, 1 is a perfect circle)

5. Radius ratio (maximum radius/minimum radius)

The diameter and area measurements are related to the size-based classification, whereas aspect ratio, radius ratio and circularity are measurements associated to test outline morphology (to assess the 'quadrate concept'). The first three measurements are self-ex- planatory; however the procedural definitions of circularity and radius ratio are detailed as follows. Circularity is a numerical representation for the curvature of the outline of the whole test (Fig. 3). It is determined from the outline of the specimen which is defined using a contrast threshold tool on the image analysis software. The software calculates the mean centroid point of the test based on the outline coordinates (tie points) around the perimeter of the test. Circularity is calculated as the ratio of the area of an object against the circle with a diameter equal to the object's maximum diameter. The maximum diameter (or maximum feret), initially expressed in pixels, represents the longest dimension of the foraminifera. It is calculated by isolating the corner pixels of the test perimeter and taking the maximum distance between each corner pixel to all other corner pixels. Once the longest dimension (in pixels) has been deduced, this value is converted to microns using the correct calibration depending on the original magnification used to image the foraminifera.

Radius ratio is a numerical value which compares the maximum and minimum test radii (see Fig. 3). After the test outline is identified using the software, a centre point of the test is ascertained. From this centre point, the maximum and minimum lengths to the edge of the test are measured. Very quadrate forms register low radius ratios as the maximum and minimum ratios are almost identical (Fig. 3, specimen 'B'). Conversely, in specimens that possess a larger final chamber, the maximum radius is increased, which increases the radius ratio (Fig.3, specimen 'A'). We morphometrically examine the opima-nana plexus to establish and test quantitative criteria to differentiate the morphospecies.

\section{Results}

Planktonic foraminifera are abundant and diverse throughout the interval studied. Preservation is moderate with recrystallisation of foraminiferal tests, some infilling and coccoliths adhered to the surface of the specimens (Plates 2-6). The preservation at Site U1334 is enhanced compared to Site 1218 (Wade and Pälike 2004), but inferior to nearby Site U1338 (Fox and Wade 2013, Hayashi et al. 2013, Beltran et al. 2014). Despite recrystallisation of some specimens, there is no observable effect on test morphology or test size. In Plates 2-5 we illustrate specimens of the opima-nana plexus arranged by size from $0.20 \mathrm{~mm}$ to $0.54 \mathrm{~mm}$. Specimens show a range of variability in 


\section{Circularity}
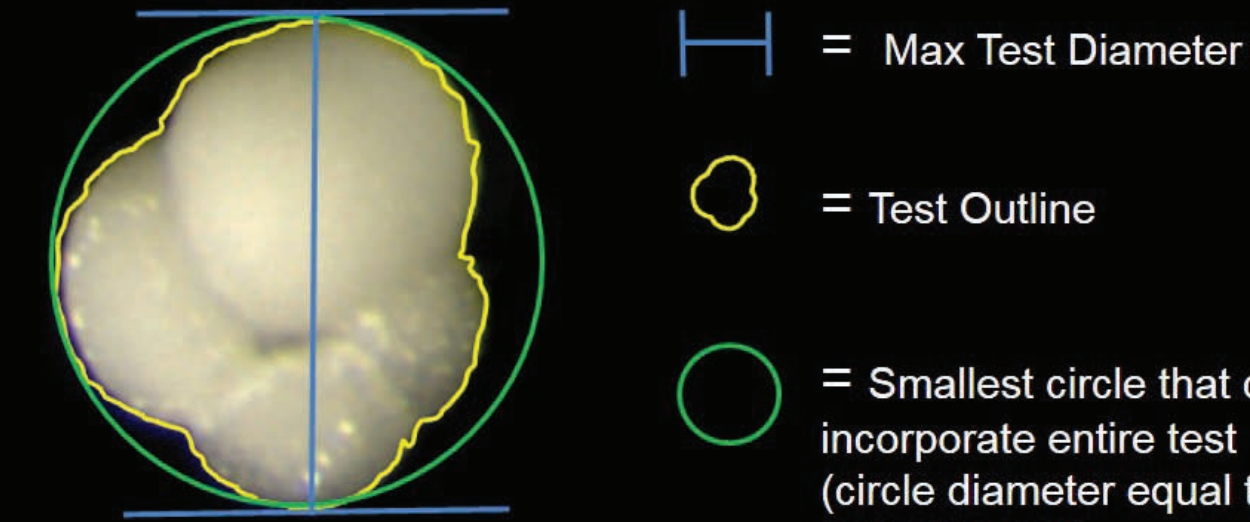

= Smallest circle that can incorporate entire test (circle diameter equal to test diameter)

\section{Radius Ratio: Maximum radius/Minimum radius}
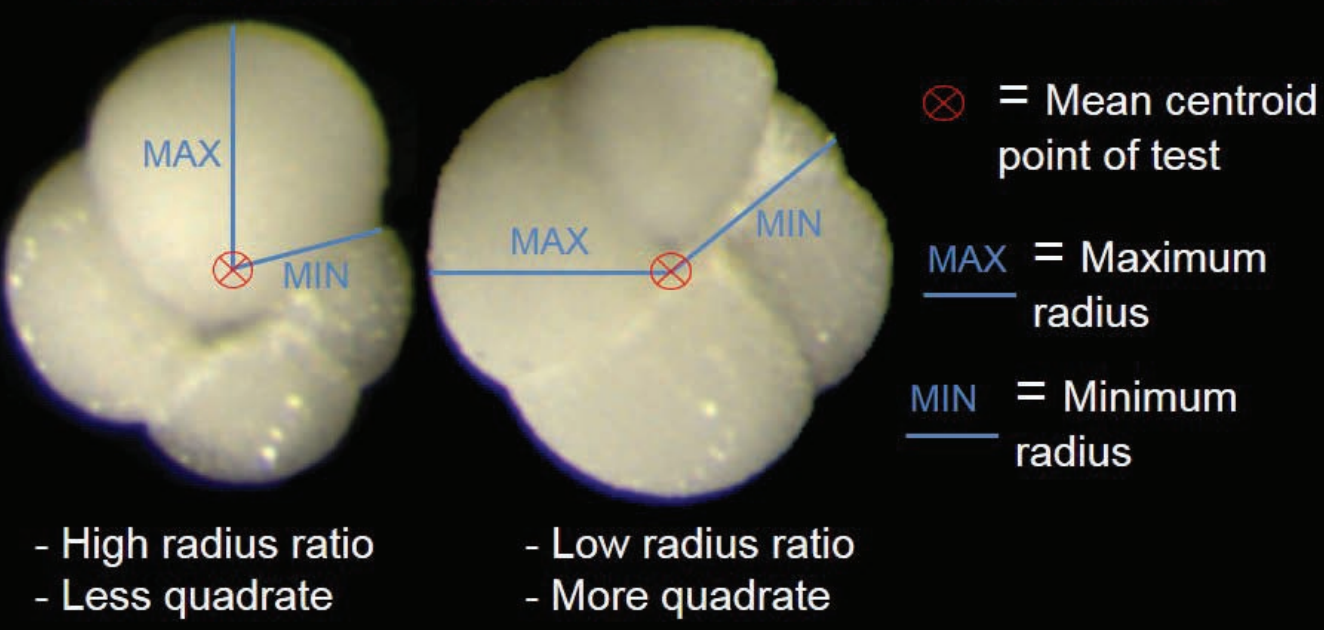

MAX = Maximum radius

MIN = Minimum radius

- High radius ratio

- Low radius ratio - More quadrate

Fig. 3. Representation of parameters used in circularity calculation and radius ratio. The circularity value is between 0 and 1 (where 1 represents a perfect circle). It is calculated using the following equation: Circularity $=(4 \times \operatorname{Area}) /(\pi \times \mathrm{MaxDia}-$ meter $\left.^{2}\right)$. For the radius ratio, both of these paragloborotaliid specimens have approximately equal test diameters, $\mathrm{A}=466$ and $\mathrm{B}=458 \mu \mathrm{m}$. However, the relationship between the maximum and minimum radii (radius ratio) is different. Specimen ' $A$ ' shows a high rate of chamber expansion and therefore the maximum radius is considerably larger than the minimum radius. Specimen 'B' shows a low chamber expansion rate with a diminutive terminal chamber, resulting in a low radius ratio.

terms of number of chambers in the final whorl $\left(4,41 \frac{1}{2}\right.$, 5), and some possess a kummerform final chamber. All specimens have a low trochospire and the majority are dextrally coiled. In Plate 6 we illustrate other species from Site U1334.

We investigated the maximum size of the opimanana plexus (Fig.4). As the astronomical age model for the Oligocene at Site U1334 is still in development, we have plotted all our figures against depth. The maximum size is relatively stable from the base of the studied section to $204 \mathrm{~m}$ with a maximum size of specimens ranging between 0.40 and $0.44 \mathrm{~mm}$. From 192 to $168 \mathrm{~m}$ the maximum size of specimens is highly variable between 0.48 and $0.56 \mathrm{~mm}$, increasing to a maxi- 
Size (mm)

$\begin{array}{lllllllllllll}0.15 & 0.20 & 0.25 & 0.30 & 0.35 & 0.40 & 0.45 & 0.50 & 0.55 & 0.60 & 0.65 & 0.70 & 0.75\end{array}$

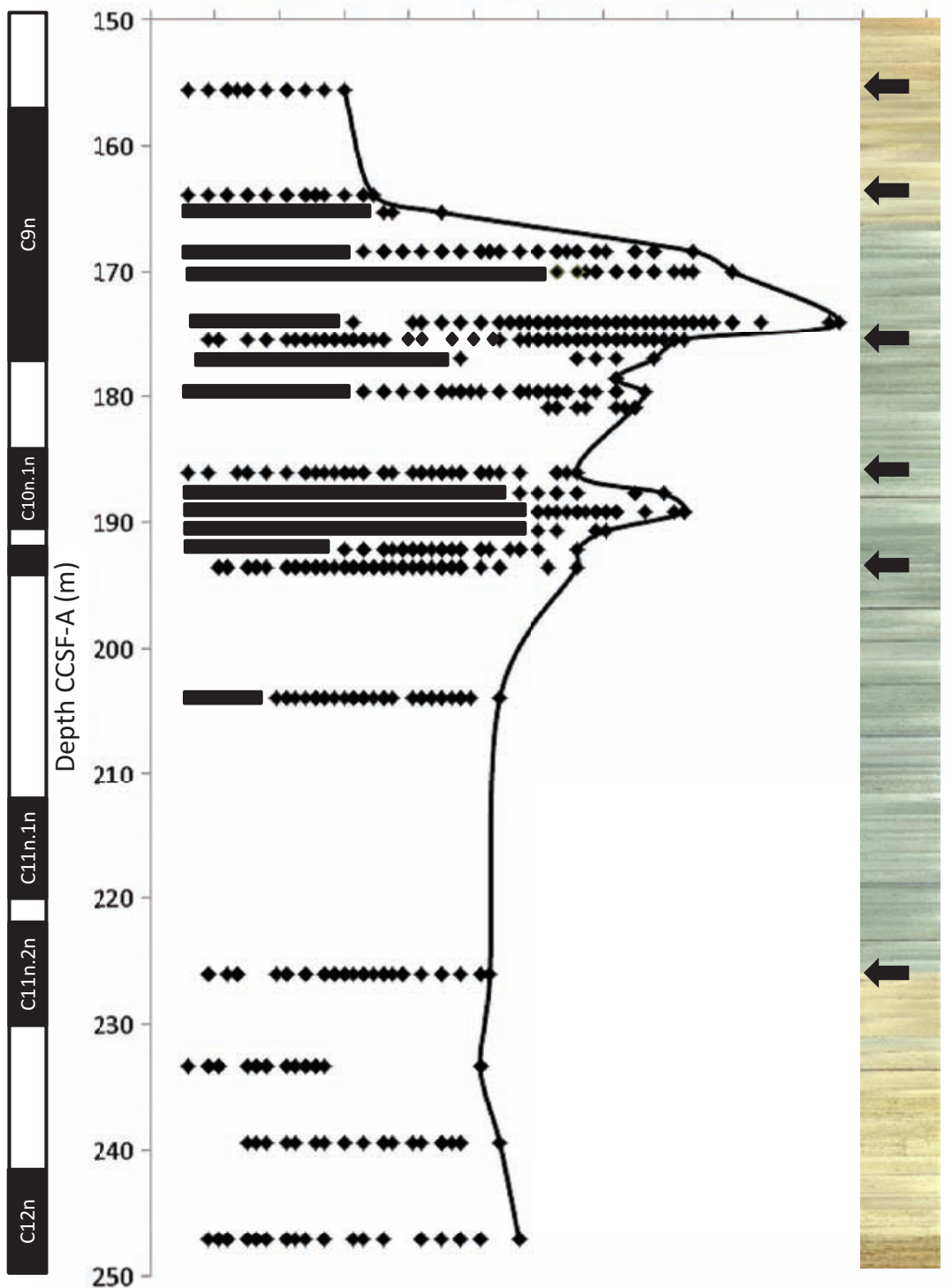

Fig. 4. Size of the Paragloborotalia opima-nana plexus versus depth at Site U1334 (1215 specimens). Specimens range in size from 0.18 to $0.68 \mathrm{~mm}$. Black bars indicate the presence of $\mathrm{Pa}$ ragloborotalia opima-nana where no measurements were taken. Core image is shown on the right, arrows indicate samples used in Fig.5. mum of $0.68 \mathrm{~mm}$ at $174 \mathrm{~m}$, equivalent to $27.24 \mathrm{Ma}$. Following this peak, the maximum size decreases to $0.38 \mathrm{~mm}$ at $165 \mathrm{~m}$ and finally to $<0.32 \mathrm{~mm}$ at $164 \mathrm{~m}$.

Paragloborotalia specimens are consistently present in the 125-250 $\mu \mathrm{m}$ size fraction throughout the study. In all samples (except 17H) Paragloborotalia have a unimodal size distribution (Fig. 5). From $20 \mathrm{H}$ to $17 \mathrm{H}$ the maximum size of Paragloborotalia increases from $\sim 0.40 \mathrm{~mm}$ in $20 \mathrm{H}-5$, to $0.50 \mathrm{~mm}$ in $18 \mathrm{H}-7$ and $18 \mathrm{H}-2$, with maximum sizes of $0.60 \mathrm{~mm}$ in $17 \mathrm{H}-2$. The maximum size is reduced to $<0.40 \mathrm{~mm}$ in samples $16 \mathrm{H}-2$ and $15 \mathrm{H}-4$. Sample $17 \mathrm{H}-2$ is anomalous with a bimodal distribution in specimen size, centred at $0.25-0.35 \mathrm{~mm}$ and $0.45-0.55 \mathrm{~mm}$, with the latter having a very high abundance (nearly 100 specimens). The abundance of the largest forms increases further in sample $17 \mathrm{H}-1$, with 185 specimens in the $0.45-0.50 \mathrm{~mm}$ size fraction (Appendix 1).

\section{Discussion}

Our morphometric data, coupled with our SEM analyses indicates a wide range of variability in the opimanana population with transitional specimens (Plates 2-5, Figs.4-6). The opima-nana plexus thus forms a 
Fig. 5. Size and abundance distribution of Paragloborotalia opima-nana plexus at Site U1334. All Paragloborotalia opima-nana $>125 \mu \mathrm{m}$ were measured and counted.

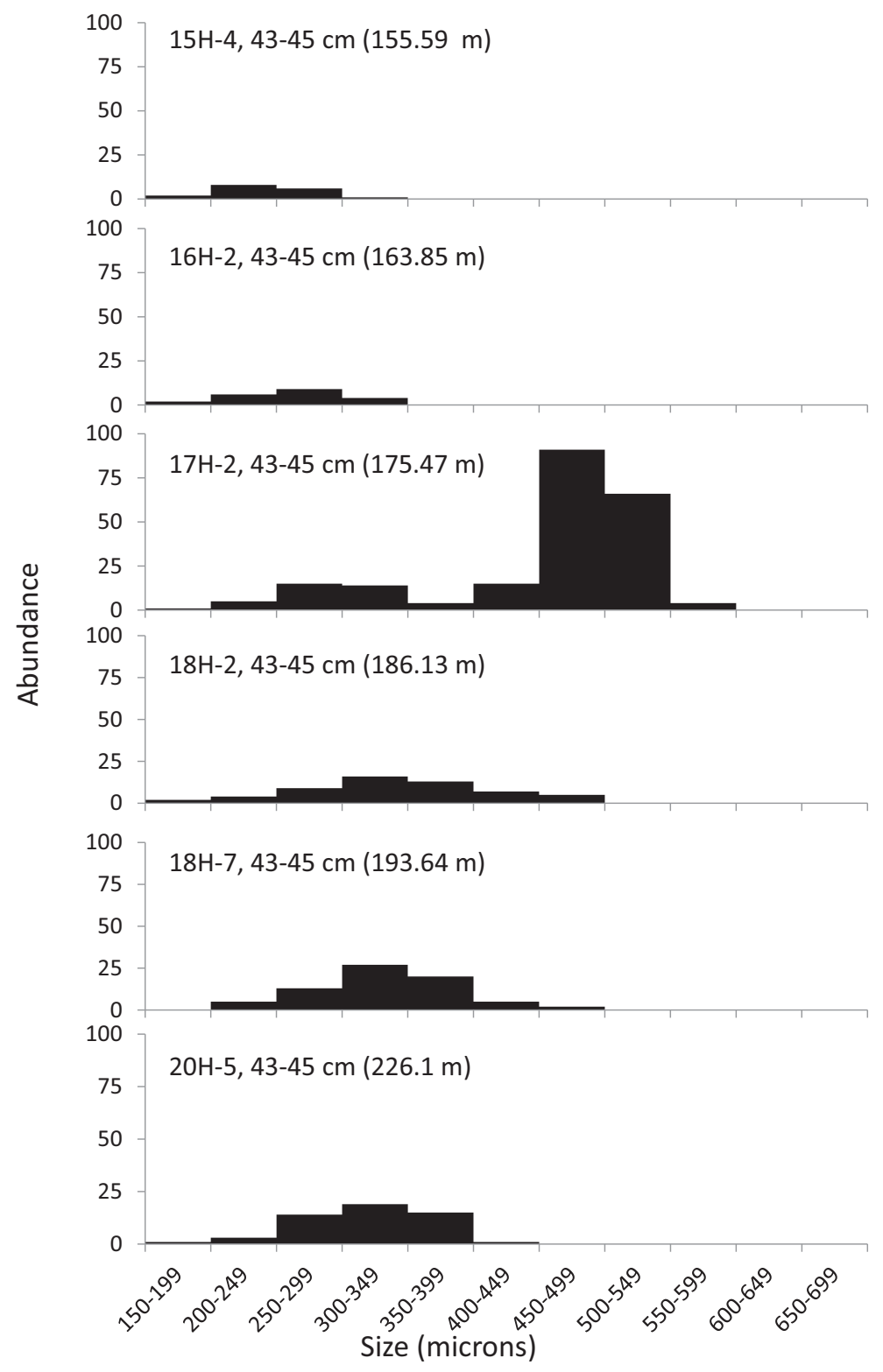

C9n and younger. Size is therefore the most important morphological parameter for taxonomic recognition of P.opima and biostratigraphic identification of the $\mathrm{O} 5 /$ O6 zonal boundary.

We place the base of Zone O6 (formerly P22) as defined by the cessation of specimens greater than $0.32 \mathrm{~mm}$ (P.opima) between sample $16 \mathrm{H}-3,43-45 \mathrm{~cm}$ and $16 \mathrm{H}-2,43-45 \mathrm{~cm}$. This is equivalent to a mean depth of $164.56 \mathrm{~m}$ CCSF-A. The sampling resolution in this study (1.5 meters) is considerably lower than in Wade et al. (2007) $(10 \mathrm{~cm})$, and therefore we have not attempted to provide a new astronomically tuned calibration for Site U1334. 


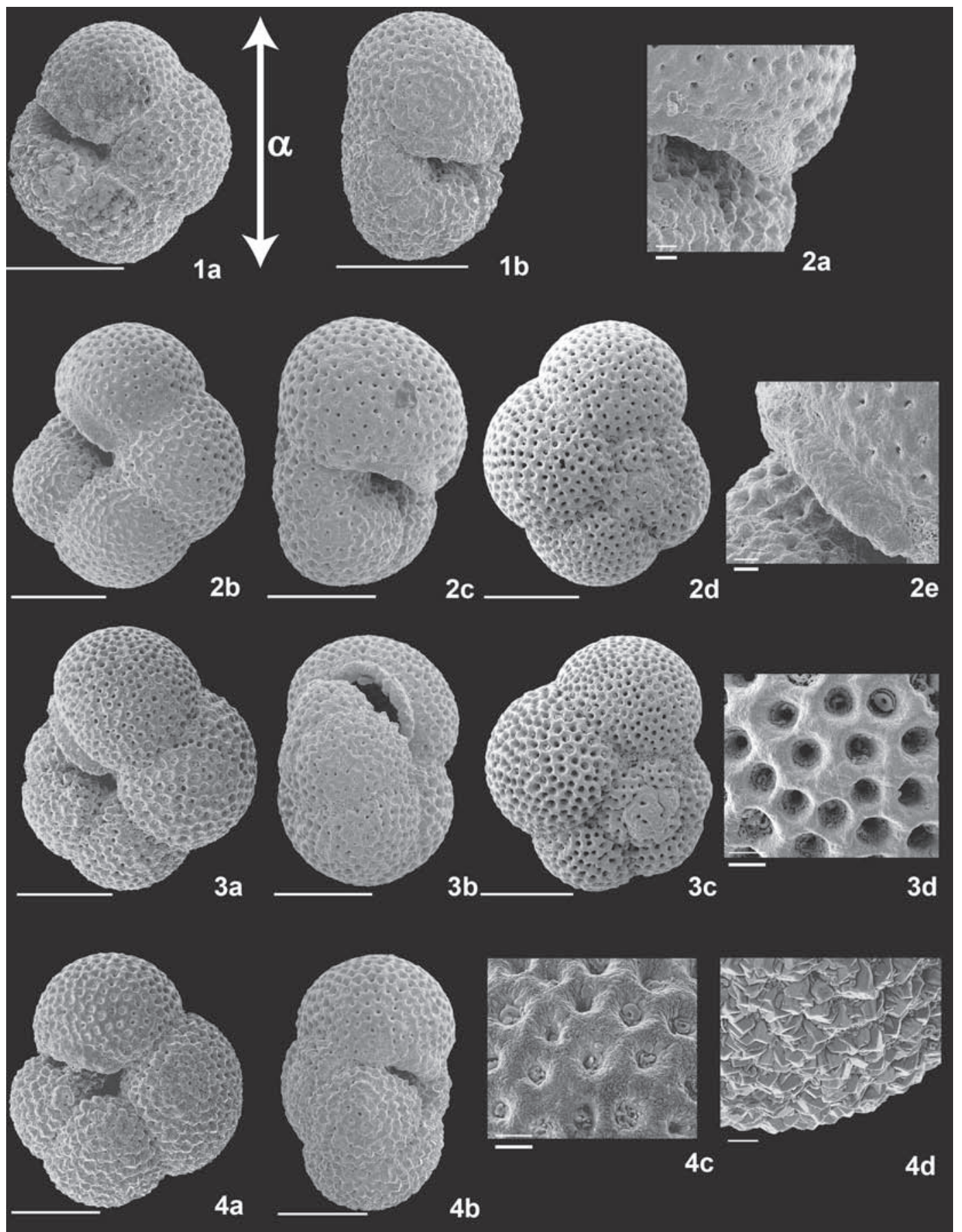

Plate 2. Paragloborotalia nana from Hole U1334A. $\alpha=$ measurement of maximum size of the specimen. $1=16 \mathrm{H}-2,43-$ $45 \mathrm{~cm}, 0.20 \mathrm{~mm}, 1 \mathrm{a}$, umbilical view, $1 \mathrm{~b}$, edge view; $2=18 \mathrm{H}-7,43-45 \mathrm{~cm}, 0.23 \mathrm{~mm}, 2 \mathrm{a}$, close up of lip in edge view, $2 \mathrm{~b}$, umbilical view, 2c, edge view, 2d, spiral view, 2e, close up of lip in umbilical view; 3 = 18H-2, 43-45 cm, $0.27 \mathrm{~mm}, 3 \mathrm{a}, \mathrm{um}-$ bilical view, 3b, edge view, 3c, spiral view, 3d, close up of wall; $4=19 \mathrm{H}-6,43-45 \mathrm{~cm}, 0.28 \mathrm{~mm}$, 4a, umbilical view, 3b, edge view, $4 \mathrm{c}$, close up of wall, $3 \mathrm{~d}$, close up of crust. Scale bar $=100 \mu \mathrm{m}$, reduced to $10 \mu \mathrm{m}$ on specimen details. 


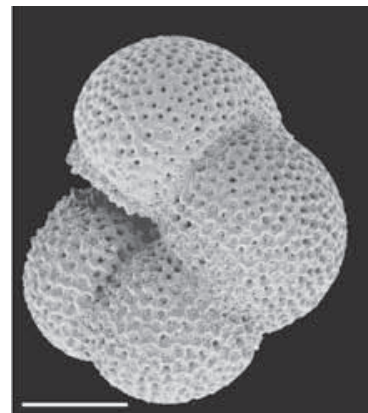

$1 \mathrm{a}$

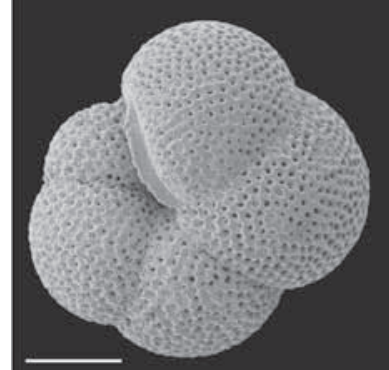

$2 a$

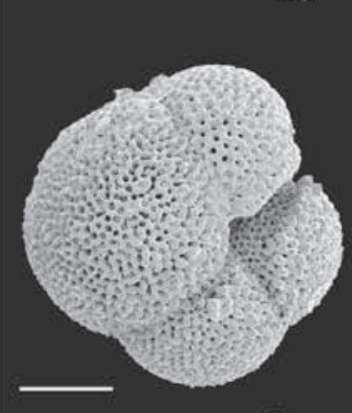

$3 a$

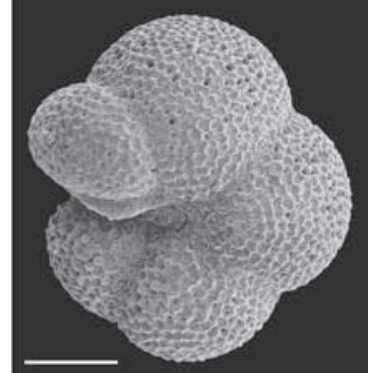

$4 a$

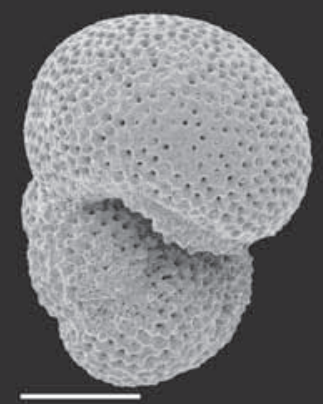

$1 b$

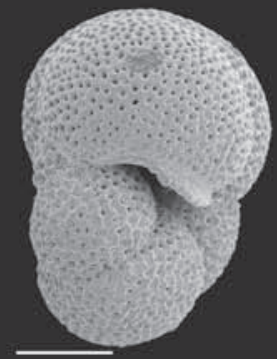

$2 \mathrm{~b}$

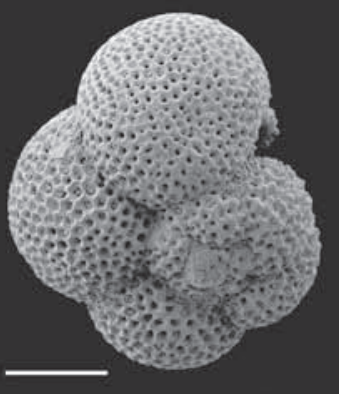

$1 c$

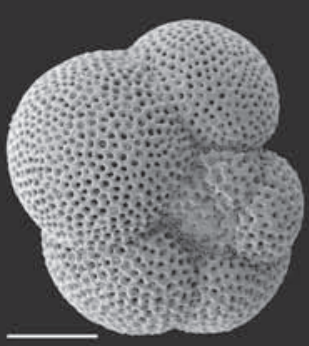

2c
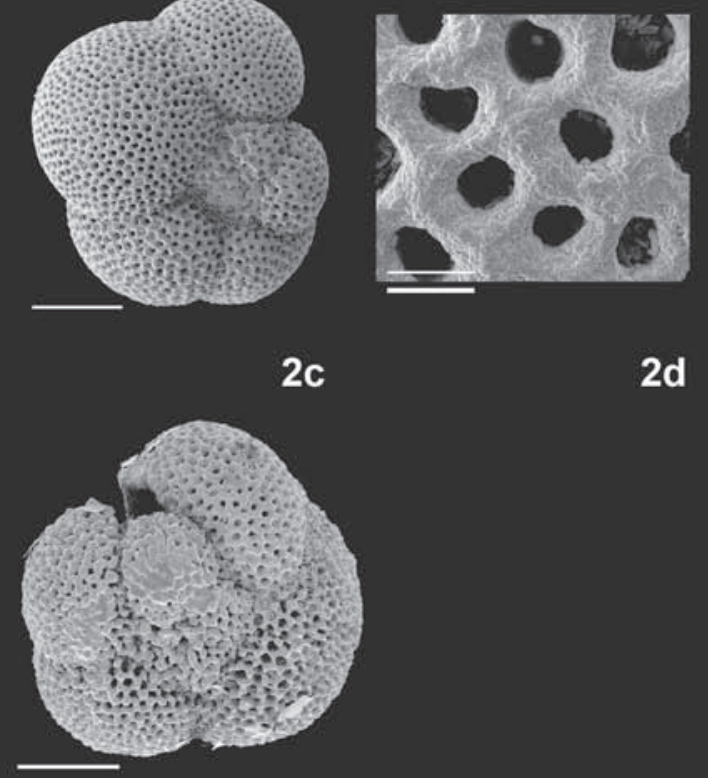

$3 \mathbf{b}$
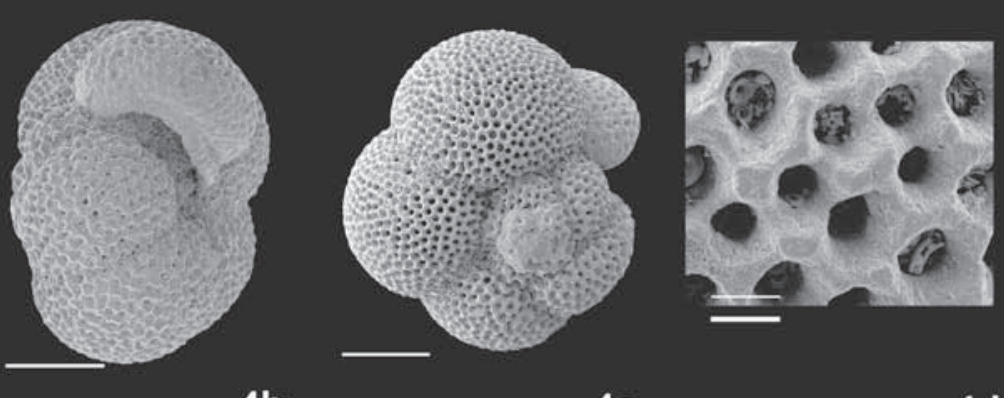

$4 c$

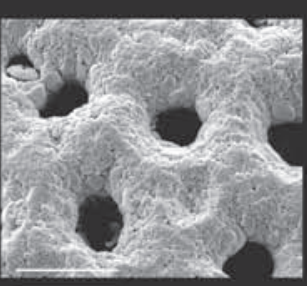

$1 d$

2d

$4 b$

4d

Plate 3. Paragloborotalia opima from Hole U1334A. $1=18 \mathrm{H}-7,43-45 \mathrm{~cm}, 0.35 \mathrm{~mm}, 1 \mathrm{a}$, umbilical view, 1b, edge view, 1c, spiral view, 1d, close up of wall; $2=17 \mathrm{H}-1,43-45 \mathrm{~cm}, 0.35 \mathrm{~mm}, 2 \mathrm{a}$, umbilical view, $2 \mathrm{~b}$, edge view, $2 \mathrm{c}$, spiral view, $2 \mathrm{~d}$, close up of wall; $3=25 \mathrm{X}-2,43-45 \mathrm{~cm}, 0.36 \mathrm{~mm}, 3 \mathrm{a}$, umbilical view, $3 \mathrm{~b}$, spiral view; $4=20 \mathrm{H}-5,43-45 \mathrm{~cm}, 0.37 \mathrm{~mm}, 4 \mathrm{a}$, umbilical view, 4b, edge view, 4c, spiral view, 4d, close up of wall. Scale bar $=100 \mu \mathrm{m}$, reduced to $10 \mu \mathrm{m}$ on specimen details. 


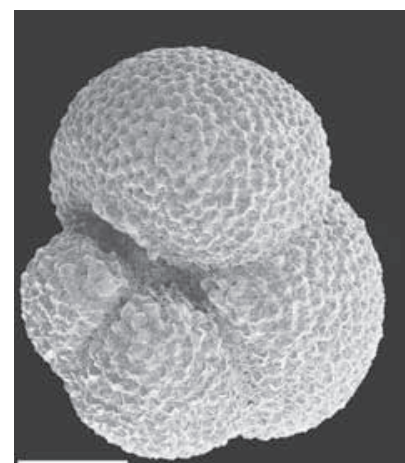

1a

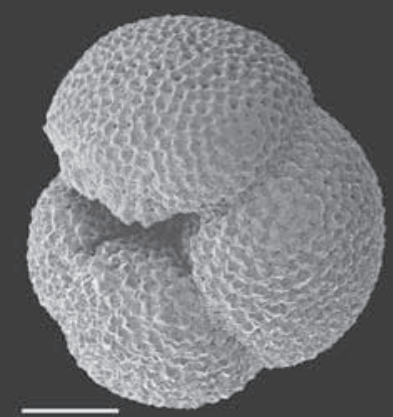

$2 a$

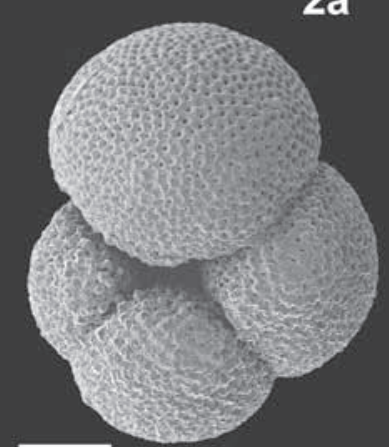

$3 a$

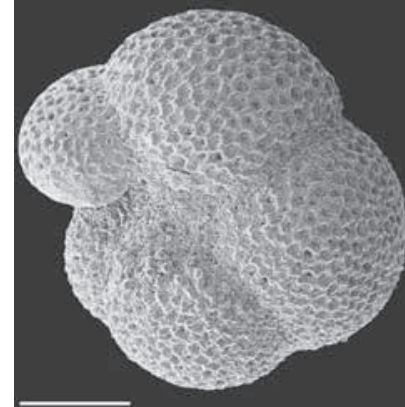

$4 a$

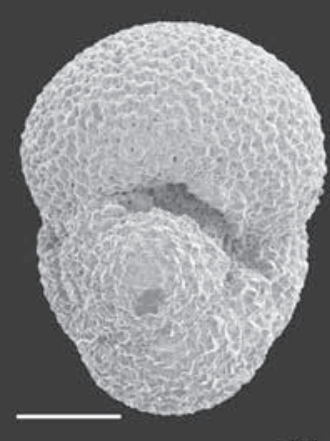

$1 \mathrm{~b}$

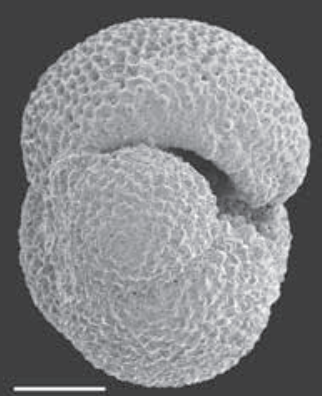

$2 b$

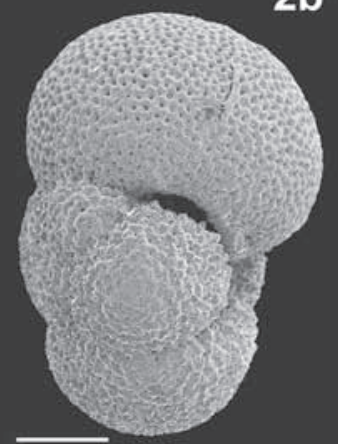

$3 b$

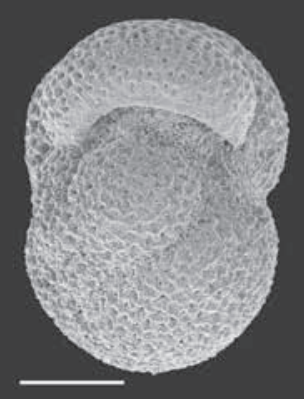

$4 b$

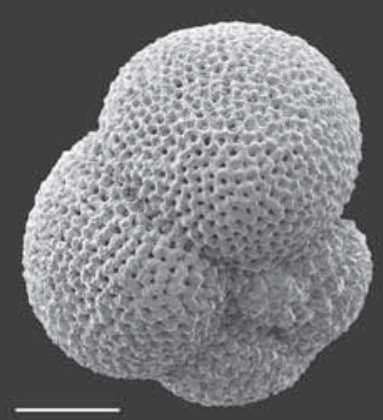

$1 c$

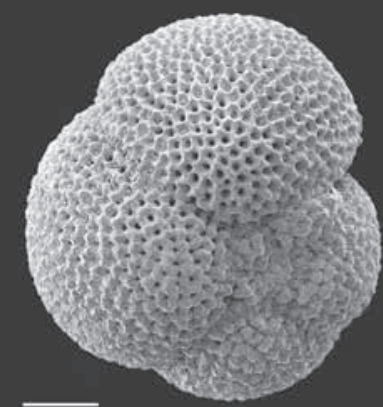

2c

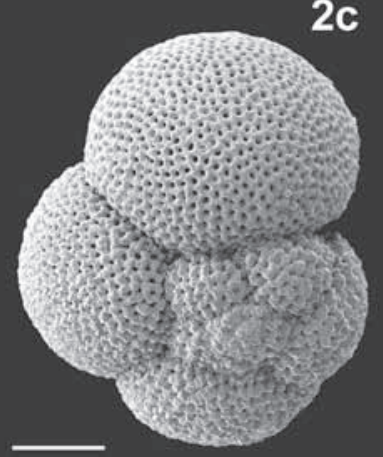

$3 c$

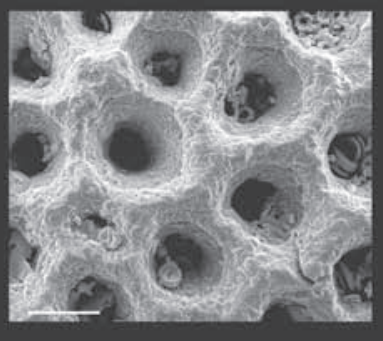

2d
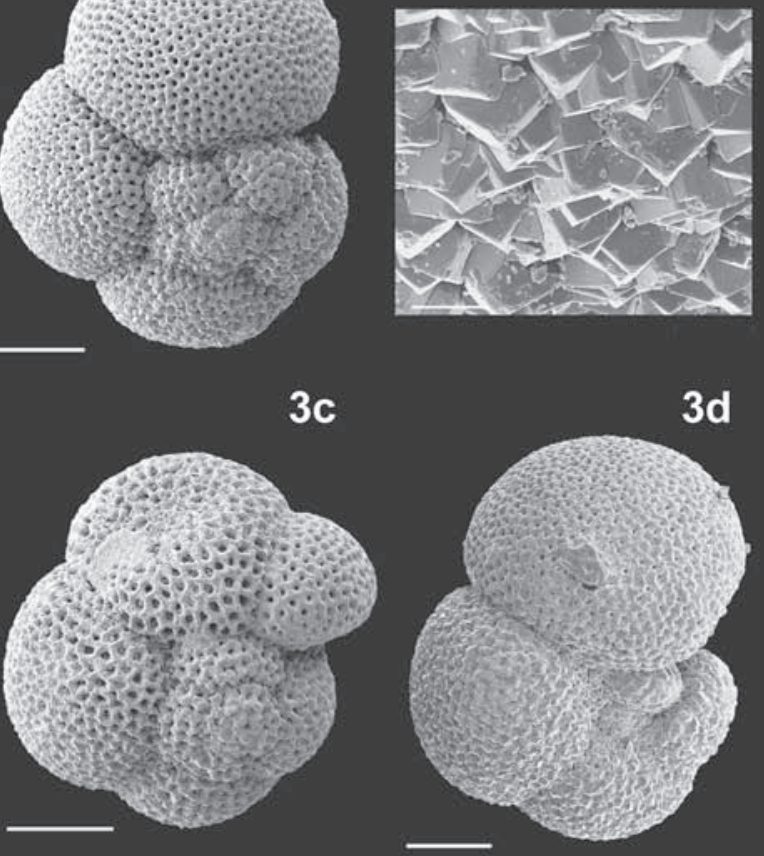

$4 c$

Plate 4. Paragloborotalia opima from Hole U1334A. $1=18 \mathrm{H}-2,43-45 \mathrm{~cm}, 0.38 \mathrm{~mm}$, 1a, umbilical view, $1 \mathrm{~b}$, edge view, 1c, spiral view, $1 \mathrm{~d}$, close up of crust; $2=16 \mathrm{H}-5,43-45 \mathrm{~cm}, 0.40 \mathrm{~mm}, 2 \mathrm{a}$, umbilical view, 2b, edge view, 2c, spiral view, 2d, close up of wall; $3=17 \mathrm{H}-1,43-45 \mathrm{~cm}, 0.46 \mathrm{~mm}, 3 \mathrm{a}$, umbilical view, 3b, edge view, $3 \mathrm{c}$, spiral view, 3d, close up of crust; $4=17 \mathrm{H}-1,43-45 \mathrm{~cm}, 0.48 \mathrm{~mm}$, 4a, umbilical view, 4b, edge view, 4c, spiral view; 5 = 20H-5, 43-45 cm, 0.48 mm, spiral view. Scale bar $=100 \mu \mathrm{m}$, reduced to $10 \mu \mathrm{m}$ on specimen details. 


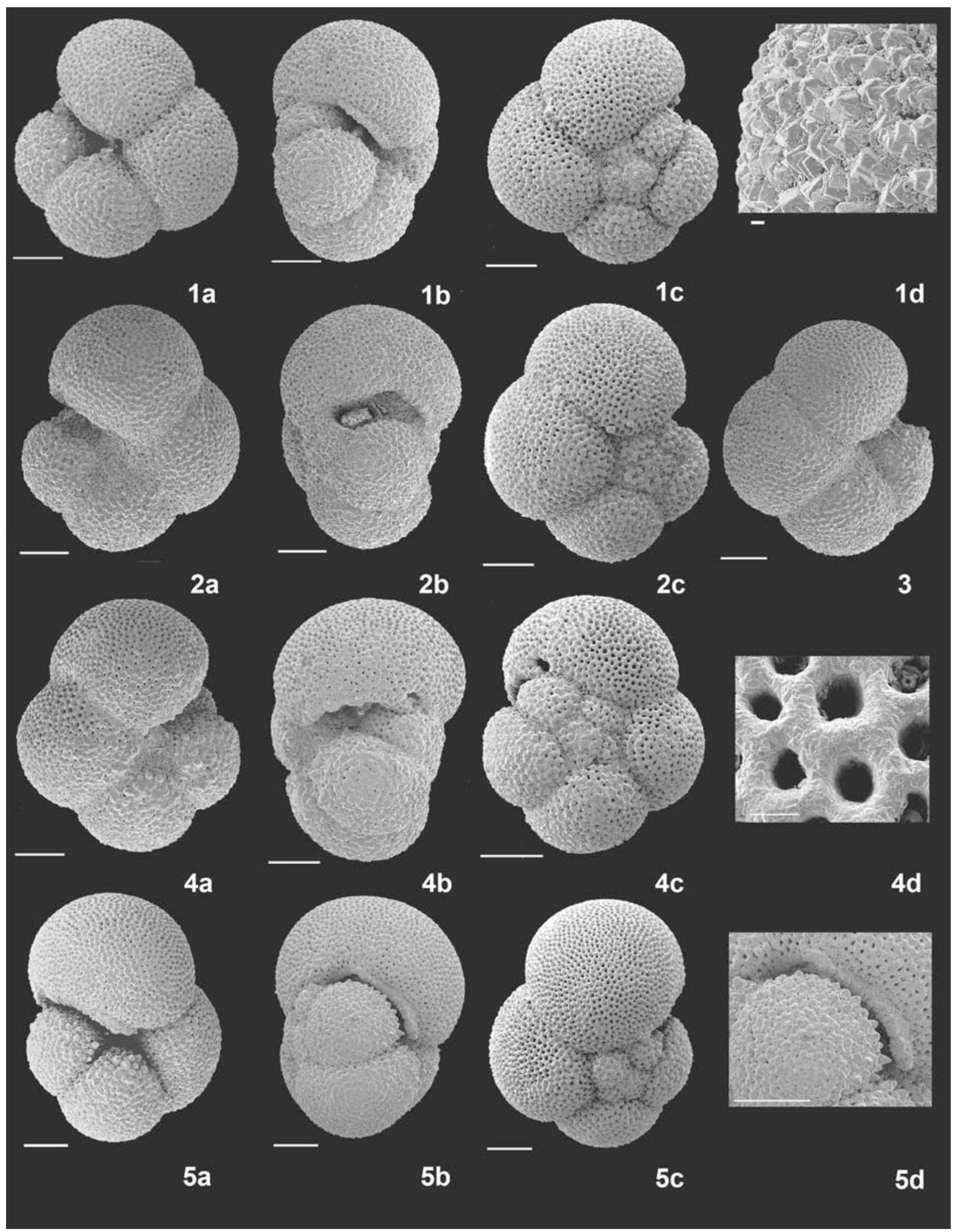

Plate 5. Paragloborotalia opima from Hole U1334A. 1 = 17H-1, 43-45 cm, $0.49 \mathrm{~mm}$, 1a, umbilical view, 1b, edge view, 1c, spiral view, $1 \mathrm{~d}$, close up of crust; $2=18 \mathrm{H}-3,43-45 \mathrm{~cm}, 0.50 \mathrm{~mm}, 2 \mathrm{a}$, umbilical view, $2 \mathrm{~b}$, edge view, 2c, spiral view; $3=16 \mathrm{H}-5,43-45 \mathrm{~cm}, 0.50 \mathrm{~mm}$, spiral view; 4 = 17H-6, 43-45 cm, $0.51 \mathrm{~mm}, 4 \mathrm{a}$, umbilical view, 4b, edge view, 4c, spiral view, $4 \mathrm{~d}$, close up of wall; $5=17 \mathrm{H}-1,43-45 \mathrm{~cm}, 0.54 \mathrm{~mm}, 5 \mathrm{a}$, umbilical view, $5 \mathrm{~b}$, edge view, $5 \mathrm{c}$, spiral view, $5 \mathrm{~d}$, close up of lip. Scale bar $=100 \mu \mathrm{m}$, reduced to $10 \mu \mathrm{m}$ on specimen details. 


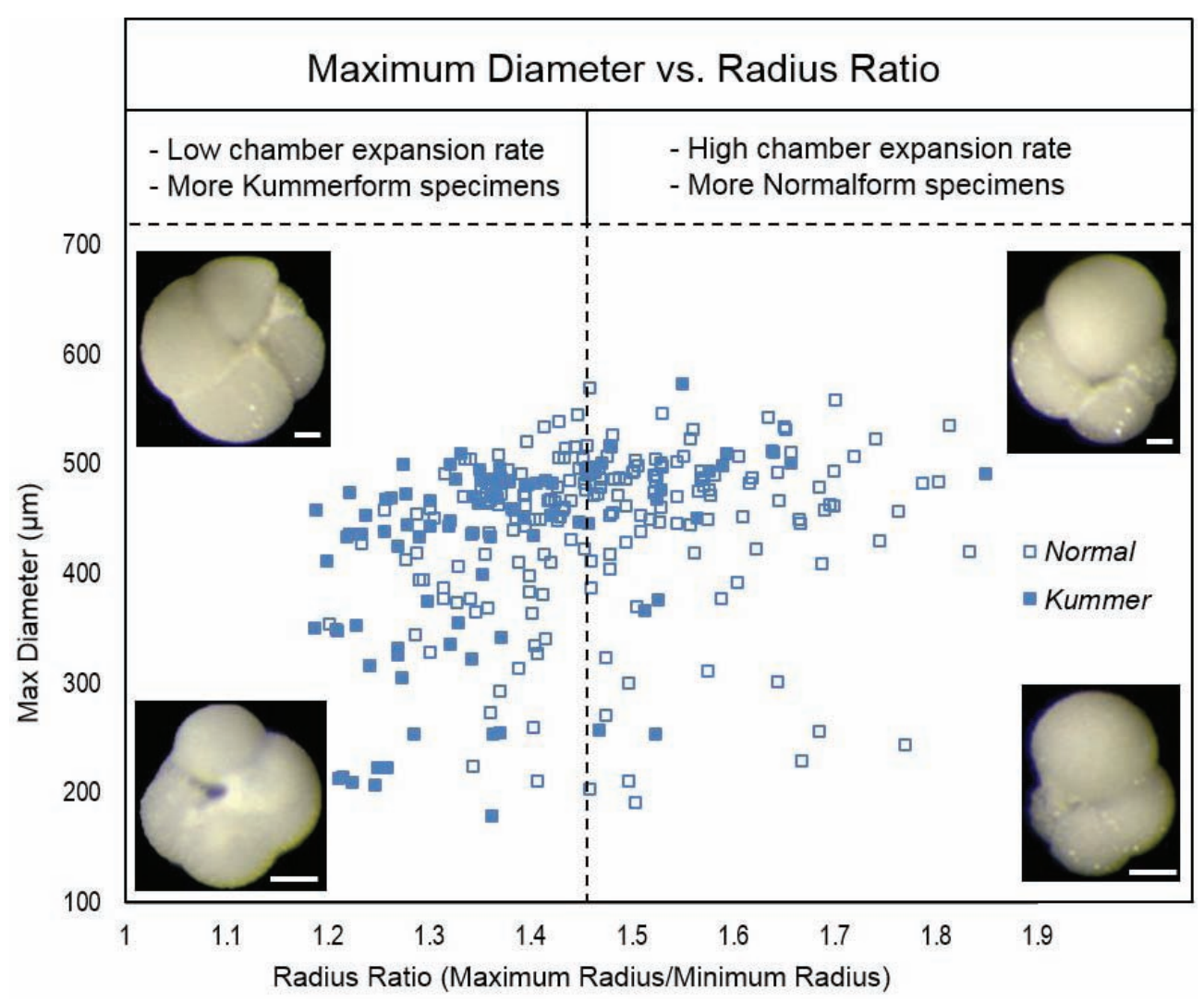

Fig. 6. Maximum test diameter plotted against radius ratio values at Site U1334 P.opima-nana specimens. We find no relationship in 'quadrateness' estimated through radius ratio and test size, i.e., the small specimens are not more quadrate. Scale bar $=50 \mu \mathrm{m}$.

\subsection{Number of chambers}

The number of chambers in the final whorl (4 versus 5 ) is not a useful characteristic in separating P.nana from P.opima (Plates 2-5). Bolli and Saunders (1985) found that most of their specimens in the 0.32$0.38 \mathrm{~mm}$ size class are 5 chambered, which appears to be the main reason why they could not confidently assign the size class to the P.opima-nana plexus (and alternatively suggested an ancestral relationship to P.mayeri) (Table 1). We examined whether the larger specimens of Paragloborotalia 'typically' had more than 4 chambers and whether the number of chambers could be used in the taxonomic distinction. We find that chamber number is not a useful characteristic as specimens ranged from 4 to $4 \frac{1}{2}$ to 5 chambers regardless of size (Plates 2-5, Appendix 1). Our data strongly suggest that these intermediate $(0.32-0.38 \mathrm{~mm})$ specimens are certainly part of the P.opima-nana plexus, and consistent with P.opima.

\subsection{Morphometrics (quadrateness)}

In the specimens that we measured, there appears to be no clear relationship or groupings when considering circularity (Appendix 2). Kummerform final chambers are common (Plates 2-5), and kummerform specimens show a tendency toward lower radius ratios (regardless of size) because they are generally more quadrate (Fig.6). However, there is no clear distinction or groupings which can be based on outline morphology. 'Quadrateness' of specimens indicates a great deal of scatter and does not provide an obvious criterion for differentiating the group (Fig. 6). In other words, it is difficult see a clear threshold which may separate P.nana and P.opima based on the 'quadrate concept'. It seems to be a general observation that the smaller P.nana specimens are often more quadrate than larger P.opima forms, but the circularity values (and radius ratio and aspect ratio) did not show any clear way of delimiting the two based on the 'quadrateness' (Fig. 6). Morphometric analysis of shape outline could not be used to differentiate the opima-nana plexus. 


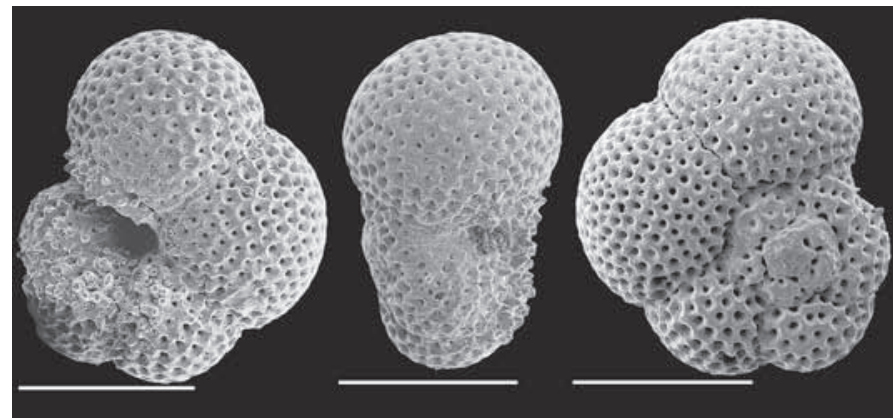

$1 \mathrm{a}$

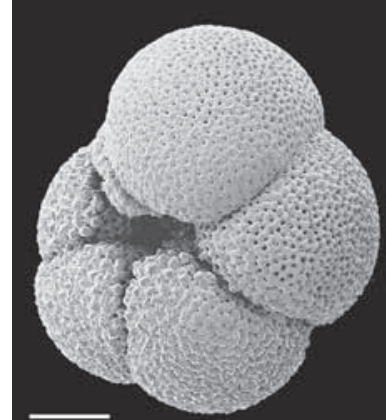

$3 a$

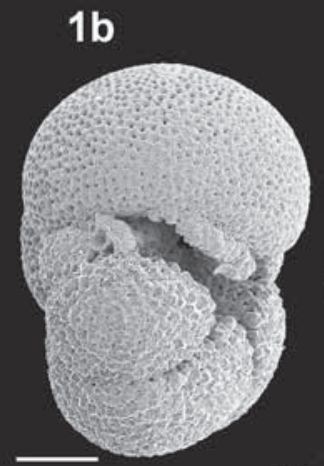

3b

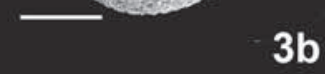

$1 c$

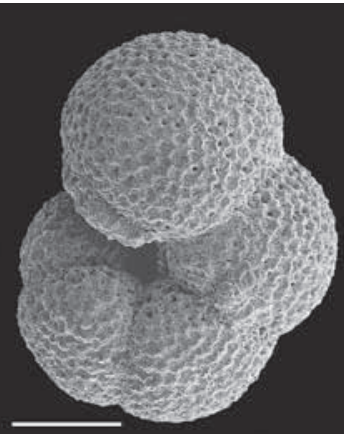

$2 a$

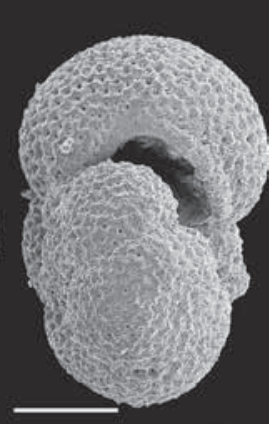

2b
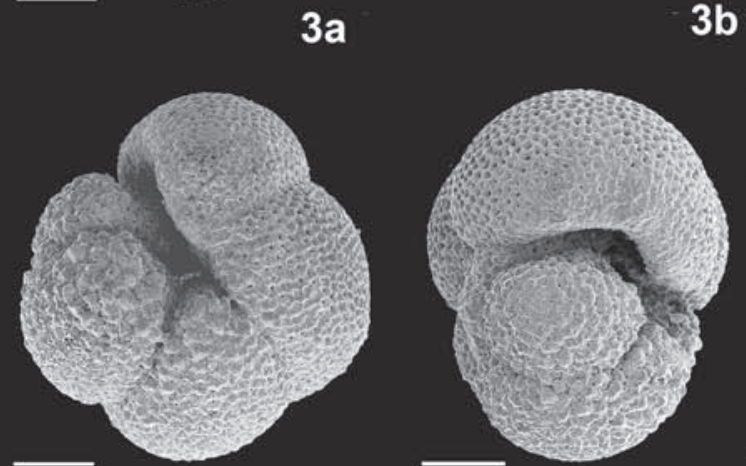

$5 \mathbf{b}$
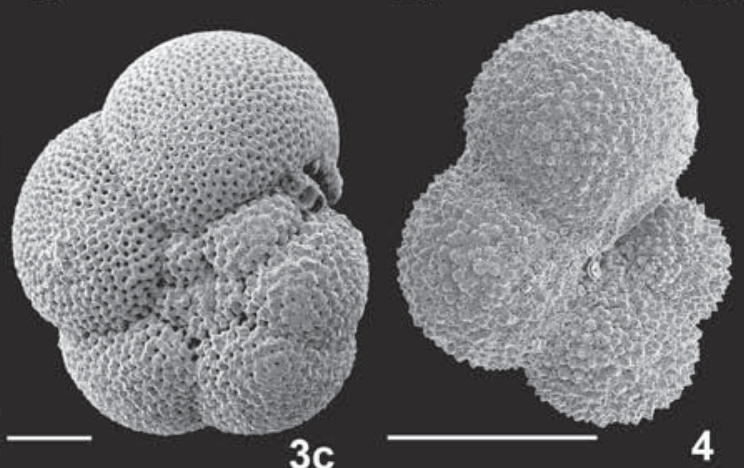

$5 a$
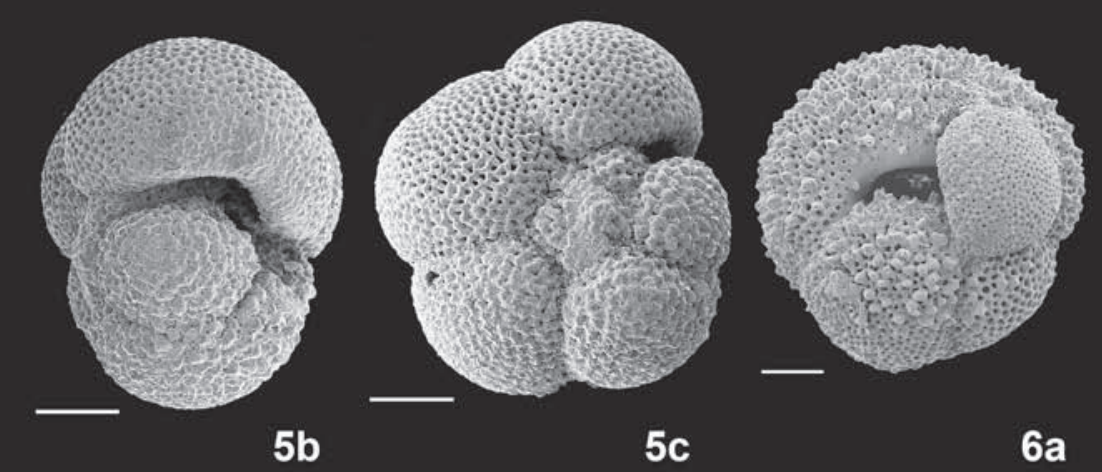

$6 a$
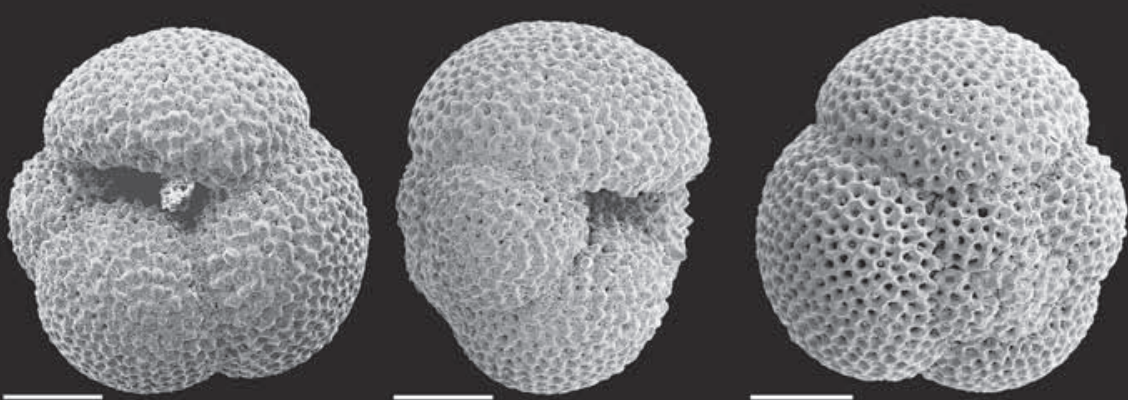

7b

7c

$6 b$

Plate 6. Oligocene planktonic foraminifera from Hole U1334A. $1=$ ? Globorotaloides eovariabilis $17 \mathrm{H}-2$, 43-45 cm, $0.20 \mathrm{~mm}, 1 \mathrm{a}$, umbilical view, 1b, edge view, 1c, spiral view; 2 = Paragloborotalia siakensis $16 \mathrm{H}-5,43-45 \mathrm{~cm}, 0.35 \mathrm{~mm}, 2 \mathrm{a}$, umbilical view, 2b, edge view; $3=$ ? Paragloborotalia semivera $17 \mathrm{H}-1,43-45 \mathrm{~cm}, 0.48 \mathrm{~mm}, 3 \mathrm{a}$, umbilical view, 3b, edge view, 3c, spiral view; 4 = Tenuitella munda $18 \mathrm{H}-2,43-45 \mathrm{~cm}$, umbilical view; 5 = Paragloborotalia semivera $17 \mathrm{H}-2$, $43-45 \mathrm{~cm}, 0.46 \mathrm{~mm}, 5 \mathrm{a}$, umbilical view, 5b, edge view, 5c, spiral view; 6 = Dentoglobigerina sellii 19H-6, 43-45 cm, 6a, umbilical view, $6 \mathrm{~b}$, spiral view; 7 = Dentoglobigerina venezuelana $16 \mathrm{H}-2,43-45 \mathrm{~cm}, 7 \mathrm{a}$, umbilical view, $7 \mathrm{~b}$, edge view, $7 \mathrm{c}$, spiral view. Scale bar $=100 \mu \mathrm{m}$, reduced to $10 \mu \mathrm{m}$ on specimen details. 


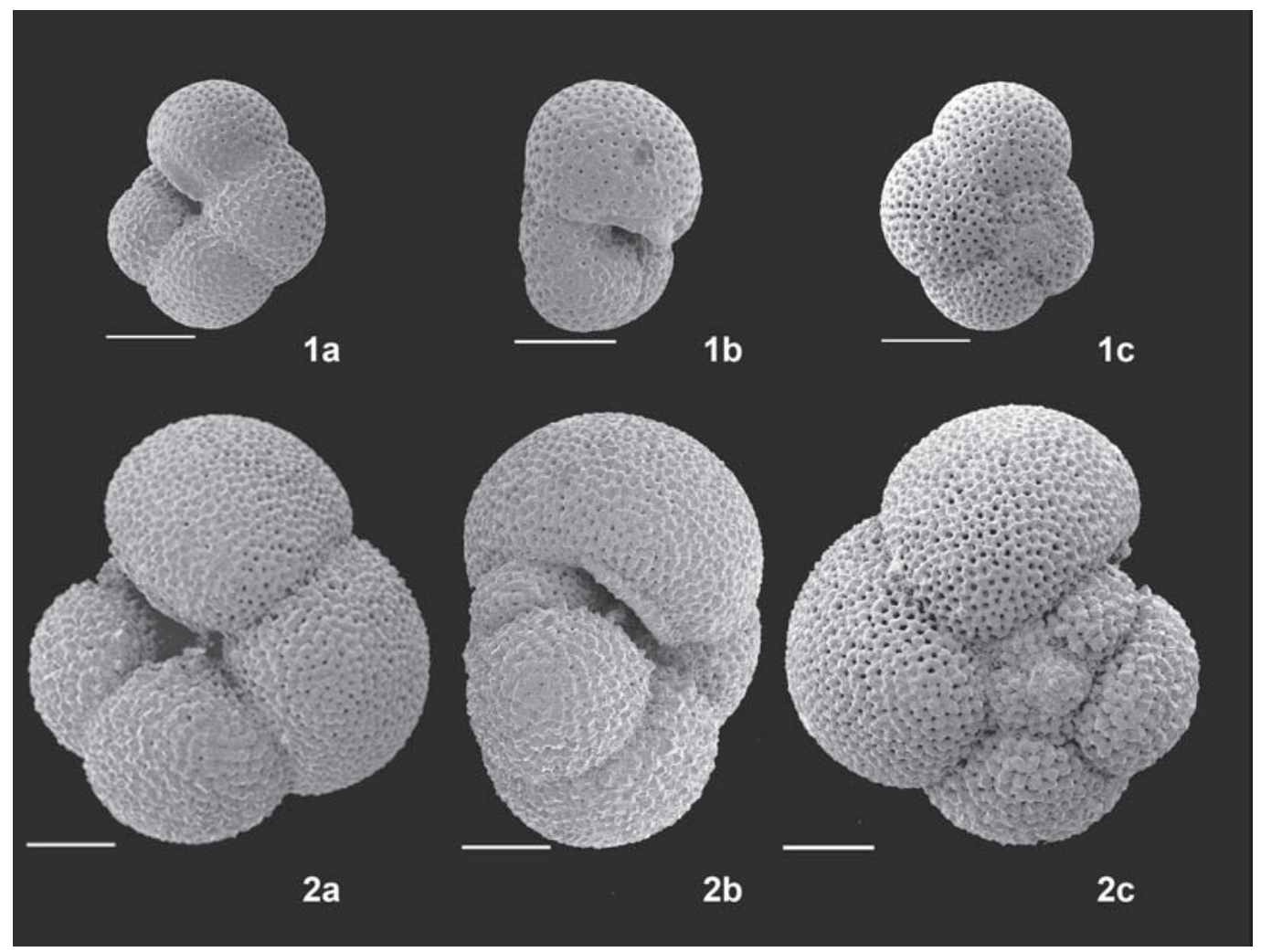

Plate 7. Specimens considered typical of Paragloborotalia nana (1a-c; $0.23 \mathrm{~mm})$ and Paragloborotalia opima (2a-c; $0.49 \mathrm{~mm}$ ) to scale. The specimens are almost identical in terms of their morphology, but specimen 7.2 is more than twice the size of specimen 7.1. Scale bar $=100 \mu \mathrm{m}$.

\subsection{Morphometrics (size)}

In our data from Site U1334 there is a large range in test diameters (Figs. 4 and 5, Appendix 1). Our study indicates that there is no distinguishable difference between P.nana and P.opima based on their morphological characteristics of chamber number and quadrateness. We have shown that 'quadrateness' is not a characteristic restricted to the smaller specimens, and that kummerform chambers are a common feature regardless of specimen size. Morphologically specimens, regardless of size, are very similar (Plates 2-5) and intermediate ('transitional') size forms impede their morphological delimitation. In Plate 7 we illustrate two specimens, which appear almost identical apart from their size, with specimen 7.2 being more than twice the size of specimen 7.1.

The variation in maximum size in the Paragloborotalia opima-nana plexus is distinct (Fig.4) with only the smaller forms continuing beyond mid Chron C9n and younger. The larger specimens have a restricted range, and do not occur higher than mid Chron C9n
(Sample U1334A, 16H-3, 43-45 cm [165.26 CCSFA]). We conclude that in order to utilise the extinction of P.opima as a biostratigraphic event, that size criteria are necessary. Of course in an evolving clade, it is always difficult and highly subjective to decide where one species ends and another begins when there is no obvious place to split the two. Our proposal is to primarily follow the criteria of Bolli and Saunders (1985) but with all specimens greater than $0.32 \mathrm{~mm}$ considered P.opima. Subdivision of the opima-nana plexus using other criteria is difficult to apply and does not allow its biostratigraphic utility. The advantage of the size criterion is that it is objective and can be used reliably and concisely. The restriction at $<0.32 \mathrm{~mm}$ is consistent with the original concept by Bolli (1957) and the size criteria of Bolli and Saunders (1985). This criterion also eliminates the intermediate 'transitional' forms (Table 1). Critically, our SEM and morphometric studies indicate that the $0.32-0.38 \mathrm{~mm}$ intermediate forms are consistent with the morphospecies concept of P.opima (and are not related to P.mayeri as suggested by Bolli and Saunders 1985), and do not ex- 
tend into the uppermost Oligocene. Different size criteria may be necessary in other localities (e.g., Atlantic Ocean), and oligotrophic settings where paragloborotaliids are less abundant. Size is not usually an attribute used to delimit morphospecies of planktonic foraminifera, though this practice is readily used in calcareous nannofossil taxonomy. Young (1990) conducted morphometric analysis on the nannofossil genus Reticulofenestra and faced similar issues with dividing species on size and evolutionary concepts.

\subsection{Progressive giantism of Paraglobo- rotalia opima: a micro- and macroevolutionary perspective}

During growth, planktonic foraminifera increase their test size sequentially through the addition of chambers, all of which are retained and preserved in each individual fossil test. Therefore, all stages of growth (ontogenetic stages) are preserved and can be examined in a single specimen. We can thus determine the microevolutionary change in ontogeny between ancestral and descendant populations within a lineage. For example, heterochrony, which can be defined as change in rate and/or timing of development (e.g., McNamara 1986, McKinney and McNamara 1991), is often accompanied by size changes and has been directly implemented in a number of instances of evolutionary change in planktonic foraminifera (Macleod et al. 1990, Wei 1994a, Kelly et al. 1996, 2001, Desmares et al. 2003, 2008). Descendant populations may pass through fewer or more ontogenetic stages than their ancestral form, resulting in the heterochronic states of paedomorphosis and peramorphosis respectively (e.g., McNamara 1986).

Although the sutures between chambers of the earliest whorl(s) are often indistinct (Plates 2 to 5), our light microscope and SEM studies of specimens of the P.opima-nana plexus reveals that P.opima typically possesses the same number of total chambers as P.nana. Comparison of Plate 2 (P.nana) with Plates 3-5 (P.opima) demonstrates the overall similarity in total chamber number, although the secondary 'crust' calcification impedes precise chamber delimitation towards the proloculus. Both morphotypes vary their total chamber number between approximately eight and thirteen, but this variation is consistent between both morphotypes regardless of size. Paragloborotalia opima therefore passes through the same number of ontogenetic stages as the ancestral P.nana, yet develops to dramatically larger sizes. Thus, we consider this to be an intriguing case of giantism rather than an example of heterochrony (see McNamara 1986 for an explanation of the differences). We invoke autapomorphic giantism as per Gould and MacFadden (2004), with body size increase on a single branch (P.opima) without impacting co-occurring ancestral taxa (P.nana). The giantism is not necessarily congruent with a 'true' speciation event (cladogenetic branching), particularly as there is morphological intergradation between the two end-member morphotypes of P.opima. However, the giantism event produced the stratigraphically useful P.opima morphotype and therefore it is expedient to preserve both P.nana and P.opima as separate (morpho)species.

Each radiation in planktonic foraminifera displays macroevolutionary trends in test size that follow Cope's Rule (e.g., Gould 1988, Arnold et al. 1995). Maximum test sizes clearly increase throughout these radiations, though various explanations and causal mechanisms have been proposed for the observed trends (see Gould 1988, Arnold et al. 1995, Schmidt et al. 2004a, 2004b, 2006). Given the macroevolutionary disposition of planktonic foraminifera to generally increase in size over time, and the preferential extinction of larger taxa (or at least survival of smaller taxa; Norris 1991), it is no surprise that the microevolutionary trends of the P.opima-nana plexus somewhat reflect this encompassing macroevolutionary pattern. Paragloborotalia nana gave rise to the larger P.opima, with both end-members (and transitional forms) co-existing until the extinction of P.opima. Paragloborotalia nana then persists after the P.opima extinction into the early Miocene (Fig. 1). We find an increase in the variance of size in the opima-nana plexus in the mid to late Oligocene as the maximum size increases but the smaller forms are still present (Figs. 4 and 5). Our data conform to Cope's Rule sensu lato (Stanley 1973, Bell 2014), in that the maximum size increases but the smaller individuals still remain. It is common for ancestral morphospecies (e.g., P.nana) to co-exist with their descendants (e.g., P.opima); palaeontological phylogenies often exhibit a "budding" configuration (see Pearson 1998 and references therein; also Aze et al. 2011). However, if size is the primary (and perhaps only) character for delimiting the morphospecies, then does the rise of P.opima represent a 'true' evolutionary event (i.e. speciation), or simply phenotypic variation in P.nana (i.e. intraspecific variation)?

The abrupt extinction bioevent of the larger forms could perhaps be cited as de facto evidence for previous speciation (rather than intraspecific size variation), even 
though precise determination of the initial speciation bioevent may be unclear. Given the wealth of evidence for multiple cryptic species in most single, modern morphospecies (e.g., Darling and Wade 2008), it is likely that many morphological transitions in the fossil record that appear gradual (anagenetic) in nature may mask speciation events and thus taxonomic diversity.

Our results indicate that the size changes in the Paragloborotalia opima-nana plexus through the Oligocene are complex. The population appears to have relative stasis from the base of the studied section to $200 \mathrm{~m}$ (CCSF-A) (Fig.4). This is followed by more erratic changes in size, with peak sizes between 175 and $168 \mathrm{~m}$ ( 27.31 to $26.97 \mathrm{Ma}$ ). Through the studied interval the mode of distribution in the larger size fractions increases (Fig.5). Most populations indicate a unimodal and symmetric distribution of size, except Sample $17 \mathrm{H}-2$, $43-45 \mathrm{~cm}$ (175.47 CCSF-A, 27.31 Ma), which has a bimodal distribution, with maximum abundance peaks at $250-350 \mu \mathrm{m}$ and $450-550 \mu \mathrm{m}$ (Fig. 5). This indicates that not only do Paragloborotalia increase in size, but the change in size is accompanied by an enhanced abundance of the largest forms. The increase in both abundance and size in Sample 17H-2 may represent lineage branching and true speciation of P.opima. Unfortunately, we do not have sample weights and therefore we are unable to normalise the abundance to specimens/gram. However, our observations are verified by quantitative abundance variations at Site U1334 by Matsui et al. (2015), which show an enhanced abundance of P.opima in core $17 \mathrm{H}$.

\subsection{Size trend mechanisms and palaeoecology}

As the smaller (P.nana) forms persist after the marked extinction of the larger (P.opima) forms, the microevolutionary trend to construct larger tests in this lineage is particularly short-lived and requires an explanation. Why did P.opima increase in size during this relatively short time interval and then disappear? An organism's growth and metabolic rate is directly impacted by its body size, as such the distribution of body size is an important factor of ecosystem structure (see Wade and Twitchett 2009 for discussion). The ontogenetic growth in individual planktonic foraminifera is a complex interplay of numerous extrinsic and intrinsic factors that can affect final test size. Ecological factors have been proposed as the main driver of giantism in several studies (e.g., Simpson 1944, Alroy 1998, Kingsolver and Pfennig 2004, Clauset and Erwin
2008) and it is generally accepted that optimum conditions contribute to larger test sizes in individuals and assemblages (e.g., Hecht and Savin 1972, Hecht 1976, Schmidt et al. 2004c). This may seem obviously intuitive, but optimum conditions may also lead to quicker reproduction and hence smaller size.

A potentially informative example of microevolutionary size increase is that of the Pliocene Globoconella puncticulata-G. inflata lineage, whereby the rise of G.inflata has been described as an 'isometric giantism' (Wei 1994a, 1994b). The only difference between the two morphospecies (at least initially) is size, and increased test inflation is a consequent feature of the lineage (Wei 1994a, 1994b). This trend appears to be related to enhanced surface water stratification, which created new ecospace and thus a new setting for speciation, which in turn was filled by the larger and more inflated G.inflata, occupying greater depths in the water column (Wei 1994a, 1994b). The development of new ecospace may in turn remove a morphospace constraint, thus eliminating a barrier to speciation. A strong correlation between increasing surface water stratification and larger test sizes is also noted by Schmidt et al. (2004b) in Cenozoic assemblage data. However, unlike the evolution of G.inflata, larger P.opima forms only exist for a short duration before extinction (across all ocean basins), whereby the smaller P.nana forms continue their comparatively long stratigraphic range.

Previous authors have suggested that the distribution of P.opima and P.nana is related to ecological controls (e.g., Blow 1969, Stainforth et al. 1975). Niche separation may result in abundance peaks at a particular size (Lampert and Tlusty 2013). Our study indicates that the maximum size corresponds to maximum abundance of P.opima (Fig. 5). We find an abundance of extraordinarily large P.opima in the equatorial Pacific Ocean. We suggest that this is an ecologically driven trend related to high productivity in equatorial and coastal upwelling settings. The correlation between Paragloborotalia abundance and increases in $\delta^{13} \mathrm{C}$ (Wade et al. 2007), indicates that enhanced nutrient availability was probably instrumental in facilitating giantism. The extinction of P.opima is coincident with a prominent sediment colour change from green to yellow/brown, at $167 \mathrm{~m} \mathrm{CCSF-A} \mathrm{(Expedition} \mathrm{320/}$ 321 Scientists 2010). Colour reflectance parameters $\mathrm{a}^{*}$ and $\mathrm{b}^{*}$ show an abrupt change through the interval corresponding to the P.opima extinction (Fig. 7). The $\mathrm{a}^{*}$ data, which measures the green to red spectrum increases from $\sim 167 \mathrm{~m}$ (CCSF-A), while the $\mathrm{b}^{*}$ data (blue-yellow spectrum) shifts abruptly to more posi- 
Fig. 7. Reflectance $a^{*}$ and $b^{*}$ at Site U1334. The termination of the large Paragloborotalia opima specimens occurs within $\sim 100 \mathrm{kyr}$ of a colour change in the core. Grey arrow indicates sampling error for the extinction of P.opima.

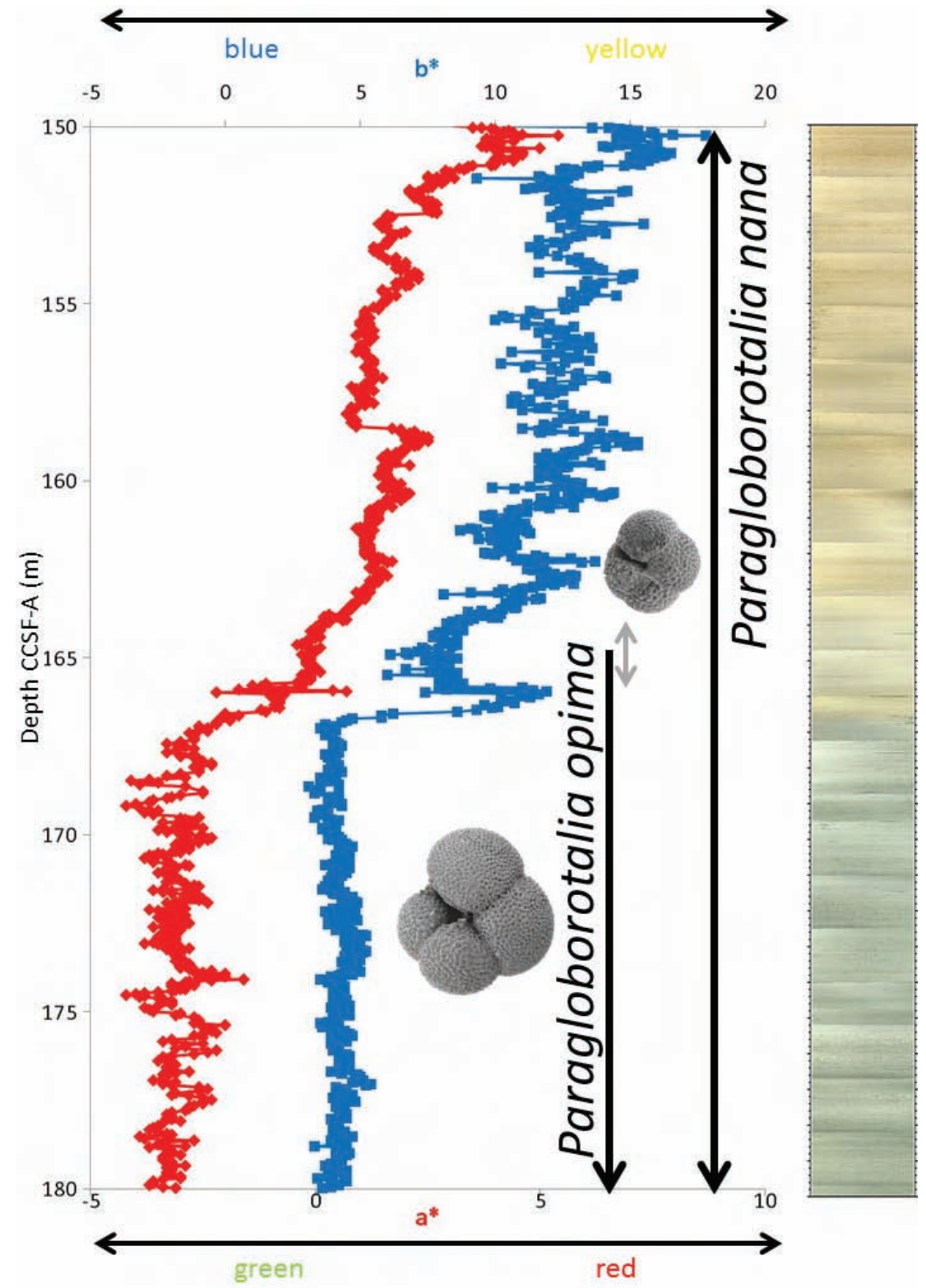

tive values at $166.5 \mathrm{~m}$ (CCSF-A) (Fig. 7). Throughout the interval dominated by the large P.opima, the magnetic susceptibility of the sediments is close to zero. The greenish grey colour is due to higher organic carbon accumulation rates leading to intensified microbial $\mathrm{Fe}$ reduction of the sediments as the site migrates through the equatorial high productivity belt (Expedition 320/321 Scientists 2010). The return to yellow/ brown sediments corresponds to the movement of Site U1334 out of the upwelling zone and the extinction of P.opima.

It is probable that the colour change is unrelated to the extinction events, after all the colour change is a local event. There is no equivalent colour change at nearby ODP Site 1218 associated with the extinction, and the extinction of P.opima is a global event that appears to be isochronous between the Indian, Pacific and Atlantic Oceans (Wade et al. 2007). However, the associated termination of the large forms (P.opima) and the colour change evokes a relationship between the two. Stainforth et al. (1975) suggested that the large P.opima were present when ecological conditions were favourable. Our data from the equatorial Pacific Ocean suggests that productivity has a major influence of P.opima size and abundance. The larger P.opima may more efficiently consume certain re- 
sources more than P.nana. Paragloborotalia opima are extremely abundant and large in the equatorial Pacific Ocean, and we postulate that this area could have been the locus of the population.

Larger organisms are typically more specialized and need greater resources. Rapid environmental alterations therefore can put larger species at an enhanced risk of extinction (Bell 2014). As planktonic foraminifera are organisms that undergo semelparous, obligate sexual mass reproduction, any major changes in productivity in this area may have impacted the fitness (and thus abundance) of the population and consequently may have hindered reproductive success and the profusion of the population globally. Our specimens attain maximum sizes of $0.68 \mathrm{~mm}$, which are larger than specimens measured from Trinidad by Bolli and Saunders (1985). Variations in productivity may also account for differing abundances and maximum sizes of P.opima in low and mid latitudes and may explain why the palaeobiogeography of P.opima is more restricted/limited compared with P.nana. Further investigations of Paragloborotalia opima-nana are required to constrain the distribution and maximum size from elsewhere, particularly from oligotrophic environments.

\subsection{Taxonomic remarks}

Our morphometric investigation allows us to reassess the taxonomy of P.nana and P.opima. The coiling direction in both P.opima and P.nana at Site U1334 is mainly but not exclusively dextral (Plates 1-5), throughout the mid Oligocene, whereas illustrated specimens from elsewhere are predominantly sinistral (e.g., Postuma 1971, Spezzaferri and Premoli Silva 1991, Leckie et al. 1993, Chaisson and Leckie 1993). A crystalline outer crust is often present, particularly on the early chambers (Plate 2.4d, 4.1d, 4.3d, 5.1d) consisting of intergrown rhombohedrons, similar to those of Neogloboquadrina pachyderma as illustrated by Olsson (1976). This feature has been observed in well preserved Paragloborotalia from Trinidad (Pearson and Wade 2009).

We suggest the following revisions to the taxonomy of P.nana and P.opima. Based on our analyses at Site $\mathrm{U} 1334,0.32 \mathrm{~mm}$ is the most appropriate size restriction that could be applied as a criterion to separate the opima-nana plexus. This is consistent with the morphometric studies of Bolli and Saunders (1985) from Trinidad.

\section{Paragloborotalia nana (Bolli, 1957)}

Plate 2

Globorotalia opima nana Bolli 1957: 118, pl.28: fig. 3a-c [Oligocene Globorotalia opima opima Zone, Cipero Fm., Trinidad].

Remarks: Commonly 4 to $4 \frac{1}{2}$ sub-circular chambers arranged in $1 \frac{1}{2}$ to 2 whorls in a low trochospire, with chambers increasing slowly in size (Plate 2). Paragloborotalia nana generally has an embracing, weakly lobate outline. The umbilical-extraumbilical aperture is a low arch, bordered by a thick, well-defined, wide lip (Plate 2e). In umbilical view, the radial, straight sutures can form a distinctive cross pattern. In spiral view the sutures are weakly to moderately incised.

Some specimens considered by us as P.nana due to their size (e.g., Plate 2.3) have 41/2 chambers and more lobate periphery. Considering these forms as P.opima could result in extension of the P.opima zone. As per Bolli and Saunders (1985) we suggest a size restriction of $<0.32 \mathrm{~mm}$.

\section{Paragloborotalia opima (Bolli, 1957)}

Plates 3-5

Globorotalia opima opima Bolli 1957: 117, pl.28: fig. 1a-c [Oligocene Globorotalia opima opima Zone, Cipero Fm., Trinidad].

Remarks: Commonly four (sometimes $4 \frac{1}{2}$ or 5 ) subcircular chambers arranged in $1 \frac{1}{2}$ to 2 whorls in a low trochospire, chambers increasing slowly and then more rapidly in size. Periphery rounded and weakly lobate. The larger P.opima forms tend to have greater chamber inflation and a more lobate periphery. Umbilicus narrow, deep with an umbilical-extraumbilical low arched aperture border by a thin lip. The lip is thinner and less pronounced than in P.nana. Kummerform final chambers are present on many specimens. The larger P.opima specimens have more incised sutures on the spiral side, though this is highly variable between specimens. The larger specimens exhibit increasing chamber inflation in the final whorl, resulting in a rather bulbous final chamber and more lobate appearance than P.nana sensu stricto (s.s.). The position of the large final chamber against the first chamber (of the final whorl) also precludes the cross-shaped suture pattern that is a common feature of P.nana s.s.

Our specimens of P.opima (Plates 3-5) are analogous to the topotypes illustrated in Stainforth et al. (1975), figure 132.1-7. As stated by Bolli and Saunders (1985) the holotype specimen chosen by Bolli 
(1957) is misleading. The paratype of opima (Bolli, 1957) illustrated in Plate 1 shares the same morphology as the majority of the Site U1334 specimens and, in agreement with Stainforth and Lamb (1981), is considered to be much more representative of the P.opima concept. The specimens $>0.32 \mathrm{~mm}$ have a restricted range and size is considered here as the main criterion to distinguish this form from P.nana, consistent with the recommendations by Bolli and Saunders (1985).

We consider the specimens illustrated as P.pseudocontinuosa in Wade et al. (2007, plate II, 1 and m) and Wade and Olsson (2009, Fig. 3b) to be consistent with the concepts of P.opima. They are similar to the paratype specimens of P.opima illustrated in Bolli and Saunders (1985, fig. 26:24-26, see also Plate 1). Indeed Bolli and Saunders (1985) fig. 26:27-29 are much more consistent with our large P.opima in terms of number of chambers and degree of chamber inflation.

\section{Conclusions}

Previous studies have qualitatively observed the differences in the Paragloborotalia opima-nana plexus; our study is the first to quantitatively document size changes, accompanied with SEM images and morphometric analysis of shape outline. Our data indicate that the opima-nana plexus forms a continuous morphocline, and no clear boundaries in shape outline or chamber number can be used to differentiate the morphospecies. The evolution and extinction of P.opima is widely used in subdivision of the Oligocene and only the smaller specimens $(<0.32 \mathrm{~mm})$ continue beyond mid Chron C9n and younger. Size is therefore the most important morphological parameter for taxonomic recognition of P.opima and biostratigraphic identification of the O5/O6 zonal boundary. Both the largest and smallest forms of the opima-nana plexus commonly have the same total number of chambers, indicating that P.opima is an example of giantism in the planktonic foraminiferal record. We suggest that the abundance and distribution of P.opima is closely related to zones of high productivity associated with equatorial divergence and coastal upwelling in low and mid latitudes.

Acknowledgements. This research was supported by UK Natural Environment Research Council (NERC) reference number NE/G014817, Marie Curie Career Integration Grant "ERAS", and a UK-IODP Rapid Response Award to BW. Scanning electron microscope analyses were funded by the University of Leeds. We thank Mark Leckie and an anonymous reviewer for insightful comments and recommendations to improve the manuscript. Our gratitude is extended to Thomas Westerhold for assistance with sample age and depth, Brian Huber for providing images of opima paratype and David King for making the location map. Fiona Keay and Shari Hilding-Kronforst assisted in SEM image editing and sample preparation respectively. We thank Mark Leckie, Bob Liska and members of the Paleogene Planktonic Foraminifera Working Group for stimulating taxonomic discussions. Samples were provided by the Integrated Ocean Drilling Program (IODP). IODP is sponsored by the U.S. National Science Foundation and participating countries.

\section{References}

Alroy, J., 1998. Cope's rule and the dynamics of body mass evolution in North American mammals. Science 280, $731-734$.

Arnold, A.J., Kelly, D.C., Parker, W.C., 1995. Causality and Cope's rule: evidence from the planktonic foraminifera. Journal of Paleontology 69(2), 203-210.

Aze, T., Ezard, T.H.G., Purvis, A., Coxall, H. K., Stewart, D.R.M., Wade, B.S., Pearson, P.N., 2011. A phylogeny of Cenozoic macroperforate planktonic foraminifera from fossil data. Biological Reviews 86, 900-927.

Bell, M., 2014. Patterns In Palaeontology: Trends of bodysize evolution in the fossil record - a growing field. $\mathrm{Pa}-$ laeontology Online 4, Article 1, 1-9.

Beltran, C., Rousselle, G., Backman, J., Wade B.S., Sicre, M.A., 2014. Paleoenvironmental conditions for the development of calcareous nannofossil acme during the late Miocene in the eastern equatorial Pacific. Paleoceanography 29, 210-222.

Blow, W.H., 1969. Late Middle Eocene to Recent planktonic foraminiferal biostratigraphy. In: Brönnimann, P., Renz, H.H. (eds.), Proceedings of the First International Conference on Planktonic Microfossils. Leiden: E. J. Brill, v. 1, p. 199-422.

Blow, W.H., Banner, F.T., 1962. The Mid-Tertiary (Upper Eocene to Aquitanian) Globigerinacea. In: Eames, F.T. and others (eds.), Fundamentals of Mid-Tertiary Stratigraphical Correlations. Cambridge, Cambridge University Press, 61-151.

Bolli, H.M., 1957. Planktonic foraminifera from the Oligocene-Miocene Cipero and Lengua formations of Trinidad, B.W.I. In: Loeblich, A. R., Jr., and collaborators, Studies in Foraminifera. United States National Museum Bulletin 215, 97-123.

Bolli, H.M., 1966. Zonation of Cretaceous to Pliocene marine sediments based on planktonic foraminifera. Boletin Informativo Asociacion Venezolana de Geología, Mineraría y Petroleo 9, 3-32.

Bolli, H.M., Saunders, J.B., 1985. Oligocene to Holocene low latitude planktic foraminifera. In: Bolli, H. M., Saunders, J. B., Perch-Nielsen, K. (eds.), Plankton Stratigraphy, Volume 1, Cambridge University Press, Cambridge, 155-262. 
Chaisson, W.P., Leckie, R.M., 1993. High-resolution Neogene planktonic foraminifera biostratigraphy of Site 806, Ontong Java Plateau (Western Equatorial Pacific). In: Berger, W.H., Kroenke, L.W., Mayer, L.A., and others (eds.), Proceedings of the Ocean Drilling Program, Scientific Results 130, 137-178.

Cifelli, R., 1982. Early occurrences and some phylogenetic implications of spiny, honeycomb textured planktonic foraminifera. Journal of Foraminiferal Research, 12, 105-115.

Coccioni, R., Sideri, M., Bancalà, G., Catanzariti, R., Frontalini, F., Jovane, L., Montanari, A., Savian, J., 2013. Integrated stratigraphy (magneto-, bio- and chronostratigraphy) and geochronology of the Palaeogene pelagic succession of the Umbria-Marche Basin (central Italy). In: Jovane, L., Herrero-Bervera, E., Hinnov, L. A., Housen, B.A. (eds.), Magnetic Methods and the Timing of Geological Processes. Geological Society, London, Special Publications 373, 111-131.

Darling, K.F., Wade, C. M., 2008. The genetic diversity of planktic foraminifera and the global distribution of ribosomal RNA genotypes. Marine Micropaleontology 67, 216-238.

Desmares, D., Grosheny, D., Beaudoin, B., 2003. Hétérochronies du développement sensu Gould chez les foraminifères planctoniques cénomaniens: exemple de néoténie dans le bassin du Western Interior américain. Comptes Rendus Palevol 2, 587-595.

Desmares, D., Grosheny, D., Beaudoin, B., 2008. Ontogeny and phylogeny of Upper Cenomanian rotaliporids (Foraminifera). Marine Micropaleontology 69, 91-105.

Expedition 320/321 Scientists, 2010. Site U1334. In: Pälike, H., Lyle, M., Nishi, H., Raffi, I., Gamage, A., Klaus A. and the Expedition 320/321 Scientists (Eds.), Proceedings of the Integrated Ocean Drilling Program, 320/321.

Fox, L.R., Wade, B. S., 2013. Systematic taxonomy of earlymiddle Miocene planktonic foraminifera from the equatorial Pacific Ocean. Integrated Ocean Drilling Program Site U1338. Journal of Foraminiferal Research 43, 374-405.

Gould, S.J., 1988. Trends as changes in variance: a new slant on progress and directionality in evolution. Journal of Paleontology 62, 319-329.

Hayashi, H., Idemitsu, K., Wade, B. S., Idehara, Y., Kimoto, K., Nishi, H., Matsui, H., 2013. Middle Miocene to Pleistocene planktonic foraminiferal biostratigraphy in the eastern equatorial Pacific Ocean. Paleontological Research 17, 91-109.

Hecht, A.D., 1976. An ecologic model for test size variation in Recent planktonic foraminifera; applications to the fossil record. Journal of Foraminiferal Research 6, 295-311.

Hecht, A.D., Savin, S.M., 1972. Phenotypic variation and oxygen isotope ratios in recent planktonic foraminifera. Journal of Foraminiferal Research 2, 55-67.

Jenkins, D. G., 1960. Planktonic foraminifers from the Lakes Entrance oil shaft, Victoria, Australia. Micropaleontology 6, 345-371.

Kelly, D.C., Arnold, A.J., Parker, W.C., 1996. Paedomorphosis and the origin of the Paleogene planktonic foraminiferal genus Morozovella. Paleobiology 22, 266-281.
Kelly, D.C., Bralower, T. J., Zachos, J.C., 2001. On the demise of the early Paleogene Morozovella velascoensis lineage: terminal progenesis in the planktic foraminifera. Palaios 16, 507-523.

Kingsolver, J. G., Pfennig, D. W., 2004. Individual-level selection as a cause of Cope's rule of phyletic size increase. Evolution 58, 1608-1612.

Lampert, A., Tlusty, T., 2013. Resonance-induced multimodal body-size distributions in ecosystems. PNAS 110, 205-209.

Leckie, R.M., Farnham, C., Schmidt, M.G., 1993. Oligocene planktonic foraminifer biostratigraphy of Hole 803D (Ontong Java Plateau) and Hole 628A (Little Bahama Bank), and comparison with the southern high latitudes. In: Berger, W.H., Kroenke, L.W., Mayer, L.A., et al. (eds.), Proceedings of the Ocean Drilling Program, Scientific Results 130,113-127.

MacLeod, N., Keller, G., Kitchell, J. A., 1990. Progenesis in late Eocene populations of Subbotina linaperta (foraminifera) from the western Atlantic. Marine Micropaleontology 16, 219-240.

Matsui, H., Nishi, H., Takashima, R., Kuroyanagi, A., Ikehara, M., Takayangi, H., Iryu, Y., 2015. Changes of Oligocene planktic foraminiferal depth habitat in the eastern equatorial Pacific (IODP Site U1334 and U1333). American Geophysical Union, Fall Meeting, San Francisco, 14-18 December, 2015, PP21C-2265.

McKinney, M.L., McNamara, K. J., 1991. Heterochrony: the evolution of ontogeny. New York, Plenum Press.

McNamara, K. J., 1986. A guide to the nomenclature of heterochrony. Journal of Paleontology 60, 4-13.

Miller, K.G., Aubry, M.-P., Khan, M.J., Melillo, A.J., Kent, D. V., Berggren, W. A., 1985. Oligocene-Miocene biostratigraphy, magnetostratigraphy, and isotope stratigraphy of the western North Atlantic. Geology 13, 257261.

Moore, T.C., Jr., Wade, B.S., Westerhold, T., Erhardt, A.M., Coxall, H. K., Baldauf, J., Wagner, M., 2014. Equatorial Pacific productivity changes near the Eocene-Oligocene boundary. Paleoceanography 29, 825-844.

Norris, R.D., 1991. Biased extinction and evolutionary trends. Paleobiology 17, 388-399.

Olsson, R.K., 1976. Wall structure, topography and crust of Globigerina pachyderma (Ehrenberg). In: Takayanagi, T., Saito, T. (eds.), Progress in Micropaleontology. Micropaleontology Press, New York, 244-257.

Olsson, R. K., Pearson, P. N., Huber, B. T., 2006. Taxonomy, Biostratigraphy, and Phylogeny of Eocene Catapsydrax, Globorotaloides, Guembelitrioides, Paragloborotalia, Parasubbotina, and Pseudoglobigerinella Olsson and Pearson n. gen. In: Pearson, P.N., Olsson, R. K., Huber, B.T., Hemleben, C., Berggren, W. A. (eds.), Atlas of Eocene Planktonic Foraminifera. Cushman Foundation Special Publication 41, 67-110.

Pälike, H., Norris, R.D., Herrle, J.O., Wilson, P. A., Coxall, H. K., Lear, C. H., Shackleton, N. J., Tripati, A.K., Wade, B.S., 2006. The heartbeat of the Oligocene climate system. Science 314 (5807), 1894-1898. 
Pälike et al. (64 co-authors), 2012. A Cenozoic record of the equatorial Pacific carbonate compensation depth. Nature 488, 609-614.

Pearson, P.N., 1998. Speciation and extinction asymmetries in paleontological phylogenies: evidence for evolutionary progress? Paleobiology 24, 305-335.

Pearson, P.N., Chaisson, W.P., 1997. Late Paleocene to middle Miocene planktonic foraminifer biostratigraphy of the Ceara Rise. In: Shackleton, N.J., Curry, W.B., Richter, C., Bralower, T.J. (Eds.), Proceeding of the Ocean Drilling Program, Scientific Results 154, 33-68.

Pearson, P.N., Wade, B.S., 2009. Taxonomy and stable isotope paleoecology of well-preserved planktonic foraminifera from the uppermost Oligocene of Trinidad. Journal of Foraminiferal Research 39, 191-217.

Poore, R.Z., 1984. Middle Eocene through Quaternary planktonic foraminifers from the southern Angola Basin: Deep Sea Drilling Project Leg 73. In: Hsü, K. J., LaBrecque, J.L., et al., Initial Reports of the Deep Sea Drilling Project 73, 429-448.

Poore, R.Z., Matthews, R.K., 1984. Late Eocene-Oligocene oxygen and carbon isotope record from South Atlantic Ocean, Deep Sea Drilling Project Site 522. In: Hsü, K.J., LaBrecque, J.L. et al., Initial Reports of the Deep Sea Drilling Project 73, Washington, D.C., U.S. Government Printing Office, 725-735.

Poore, R.Z., Tauxe, L., Percival, Jr., S. F., LaBrecque, J. L., 1982. Late Eocene-Oligocene magnetostratigraphy and biostratigraphy at South Atlantic DSDP Site 522. Geology 10, 508-511.

Poore, R.Z., Tauxe, L., Percival, Jr., S. F., LaBrecque, J.L., Wright, R., Petersen, N.P., Smith, C.C., Tucker, P., Hsü, K.J., 1983. Late Cretaceous-Cenozoic magnetostratigraphic and biostratigraphic correlations of the South Atlantic Ocean: DSDP Leg 73. Palaeogeography, Palaeoclimatology, Palaeoecology 42, 127-149.

Postuma, J.A., 1971. Manual of Planktonic Foraminifera, Amsterdam, Elsevier, 420 p.

Schmidt, D.N., Thierstein, H.R., Bollmann, J., 2004a. The evolutionary history of size variation of planktic foraminiferal assemblages in the Cenozoic. Palaeogeography, Palaeoclimatology, Palaeoecology 212, 159-180.

Schmidt, D. N., Thierstein, H. R., Bollmann, J., Schiebel, R., 2004 b. Abiotic forcing of plankton evolution in the Cenozoic. Science 303(5655), 207-210.

Schmidt, D.N., Renaud, S., Bollmann, J., Schiebel, R., Thierstein, H.R., 2004c. Size distribution of Holocene planktic foraminifer assemblages: biogeography, ecology and adaptation. Marine Micropaleontology 50, 319-338.

Schmidt, D. N., Lazarus, D., Young, J. R., Kucera, M., 2006. Biogeography and evolution of body size in marine plankton. Earth-Science Reviews 78, 239-266.

Simpson, G.G., 1944. Tempo and mode in evolution. Columbia University Press, New York.

Spezzaferri, S., 1994. Planktonic foraminiferal biostratigraphy of the Oligocene and lower Miocene in the oceanic record. An overview. Palaeontographia Italica 81, 1-187.
Spezzaferri, S., Premoli Silva, I., 1991. Oligocene planktonic foraminiferal biostratigraphy and paleoclimatic interpretation from Hole 538A, DSDP Leg 77, Gulf of Mexico. Palaeogeography, Palaeoclimatology, Palaeoecology 83, 217-263.

Stainforth, R. M., Lamb, J.L., 1981 . An evaluation of planktonic foraminiferal zonation of the Oligocene. University of Kansas Paleontological Contributions 104, 1-34.

Stainforth, R.M., Lamb, J.L., Luterbacher, H., Beard, J. H., Jeffords, R.M., 1975. Cenozoic planktonic foraminiferal zonation and characteristics of index forms. University of Kansas Paleontological Contributions 62, 1-425.

Stanley, S.M., 1973. An explanation of Cope's rule. Evolution 27, 1-25.

Wade, B.S., Olsson, R.K., 2009. Investigation of pre-extinction dwarfing in Cenozoic planktonic foraminifera. Palaeogeography, Palaeoclimatology, Palaeoecology 284, 39-46.

Wade, B.S., Pälike, H., 2004. Oligocene climate dynamics. Paleoceanography 19, PA4019, doi:10.1029/2004PA001 042 .

Wade, B.S., Twitchett, R., 2009. Extinction, dwarfing and the Lilliput effect. Palaeogeography, Palaeoclimatology, Palaeoecology 284, 1-3.

Wade, B.S., Berggren, W. A., Olsson, R. K., 2007. The biostratigraphy and paleobiology of Oligocene planktonic foraminifera from the equatorial Pacific Ocean (ODP Site 1218). Marine Micropaleontology 62, 167-179.

Wade, B.S., Pearson, P.N., Berggren, W.A., Pälike, H., 2011. Review and revision of Cenozoic tropical planktonic foraminiferal biostratigraphy and calibration to the geomagnetic polarity and astronomical time scale. Earth Science Reviews 104, 111-142.

Wei, K.-Y., 1994a. Allometric heterochrony in the PliocenePleistocene planktic foraminiferal clade Globoconella. Paleobiology 20, 66-84.

Wei, K.-Y., 1994b. Stratophenetic tracing of phylogeny using SIMCA pattern recognition technique: a case study of the late Neogene planktic foraminifera Globoconella clade. Paleobiology 20, 52-65.

Westerhold, T., Röhl, U., Wilkens, R., Pälike, H., Lyle, M., Jones, T. D., Bown, P., Moore, T., Kamikuri, S., Acton, G., Ohneiser, C., Yamamoto, Y., Richter, C., Fitch, P., Scher, H., Liebrand, D., and the Expedition 320/321 Scientists, 2012. Revised composite depth scales and integration of IODP Sites U1331-U1334 and ODP Sites 1218-1220. In: Pälike, H., Lyle, M., Nishi, H., Raffi, I., Gamage, K., Klaus, A., and the Expedition 320/321 Scientists, Proceedings of the Integrated Ocean Drilling Program, 320/321: Tokyo (Integrated Ocean Drilling Program Management International, Inc.); doi:10.2204/iodp.proc.320321.201.2012

Young, J., 1990. Size variation of Neogene Reticulofenestra coccoliths from Indian Ocean DSDP Cores. Journal of Micropalaeontology 9, 71-85.

Manuscript received: August 24, 2015; rev. version accepted: March 14, 2016. 
444 B. S. Wade et al.

The pdf version of this paper includes an electronic supplement:

Tables of content - Electronic Supplementary Material (ESM)

Appendix 1: Size measurements of Paragloborotalia opima-nana plexus at Site U1334.

Appendix 2: Circularity and Radius Ratio.

Please download the electronic supplement and rename the file extension to .zip (for security reasons Adobe does not allow to embed .exe, .zip, rar etc. files). 